\title{
Allergy Enhances Neurogenesis and Modulates Microglial Activation in the Hippocampus
}

\author{
Barbara Klein 1,2, Heike Mrowetz ${ }^{1,2}$, Josef Thalhamer ${ }^{3}$, Sandra Scheiblhofer ${ }^{3}$, \\ Richard Weiss ${ }^{3 \dagger}$ and Ludwig Aigner ${ }^{1,2 * \dagger}$
}

\begin{abstract}
${ }^{1}$ Institute of Molecular Regenerative Medicine, Paracelsus Medical University, Salzburg, Austria, ${ }^{2}$ Spinal Cord Injury and Tissue Regeneration Center Salzburg (SCl-TReCS), Paracelsus Medical University, Salzburg, Austria, ${ }^{3}$ Division of Allergy and Immunology, Department of Molecular Biology, University of Salzburg, Salzburg, Austria
\end{abstract}

Allergies and their characteristic $T_{\mathrm{H}} 2$-polarized inflammatory reactions affect a substantial part of the population. Since there is increasing evidence that the immune system modulates plasticity and function of the central nervous system (CNS), we investigated the effects of allergic lung inflammation on the hippocampus-a region of cellular plasticity in the adult brain. The focus of the present study was on microglia, the resident immune cells of the CNS, and on hippocampal neurogenesis, i.e., the generation of new neurons. C57BL/6 mice were sensitized with a clinically relevant allergen derived from timothy grass pollen (Phl p 5). As expected, allergic sensitization induced high serum levels of allergen-specific immunoglobulins (lgG1 and $\operatorname{lgE}$ ) and of $\mathrm{T}_{\mathrm{H}} 2$ cytokines (IL-5 and IL-13). Surprisingly, fewer Iba1 ${ }^{+}$microglia were found in the granular layer (GL) and subgranular zone (SGZ) of the hippocampal dentate gyrus and also the number of $\mathrm{lba} 1^{+} \mathrm{MHCll}{ }^{+}$cells was lower, indicating a reduced microglial surveillance and activation in the hippocampus of allergic mice. Neurogenesis was analyzed by labeling of proliferating cells with bromodeoxyuridine (BrdU) and determining their fate 4 weeks later, and by quantitative analysis of young immature neurons, i.e., cells expressing doublecortin (DCX). The number of $\mathrm{DCX}^{+}$cells was clearly increased in the allergy animals. Moreover, there were more $\mathrm{BrdU}^{+}$cells present in the hippocampus of allergic mice, and these newly born cells had differentiated into neurons as indicated by a higher number of $\mathrm{BrdU}^{+} \mathrm{NeuN}^{+}$cells. In summary, allergy led to a reduced microglia presence and activity and to an elevated level of neurogenesis in the hippocampus. This effect was apparently specific to the hippocampus, as we did not observe these alterations in the subventricular zone (SVZ)/olfactory bulb (OB) system, also a region of high cellular plasticity and adult neurogenesis.

Received: 23 March 2016 Accepted: 10 June 2016

Published: 28 June 2016

Citation:

Klein B, Mrowetz H, Thalhamer J, Scheiblhofer S, Weiss $R$ and Aigner $L$ (2016) Allergy Enhances Neurogenesis and Modulates Microglial Activation in the Hippocampus.

Front. Cell. Neurosci. 10:169. doi: 10.3389/fncel.2016.00169
Keywords: allergy, neurogenesis, microglia, systemic inflammation, hippocampus, $\mathrm{T}_{\mathrm{H}} 2$ polarization

\section{INTRODUCTION}

In comparison to the broad interest focusing on the influence of $\mathrm{T}_{\mathrm{H}} 1$ inflammatory parameters on the central nervous system (CNS; e.g., Cunningham et al., 2009; Henry et al., 2009; Jurgens and Johnson, 2012; Jurgens et al., 2012; Kahn et al., 2012; Kranjac et al., 2012; Valero et al., 2014), only a small number of studies deals with the effects of $\mathrm{T}_{\mathrm{H}} 2$ immunity on the brain (e.g., Tonelli et al., 2009; 
Sarlus et al., 2012, 2013). This is in striking contrast to the fact that chronic $\mathrm{T}_{\mathrm{H}}$ 2-polarized immune reactions, which are a main characteristic of allergies, affect a substantial and increasing part of the population world-wide (Bieber, 2011; Fiocchi, 2011; Pawankar, 2011). The WAO estimates that 400 million people in the world suffer from allergic rhinitis and 300 million from asthma (Brozek et al., 2010; Pawankar, 2011).

Allergies are misguided responses of the immune system in which normally non-pathogenic stimuli, such as tree and grass pollen, dust mites, or animal dander, lead to immune responses characterized by the synthesis of allergen-specific IgE antibodies, the activation of $\mathrm{T}_{\mathrm{H}} 2$ immune cells and the production of the key $\mathrm{T}_{\mathrm{H}} 2$ cytokines IL-4, IL-5, and IL-13 (for a review, see Bloemen et al., 2007; Galli et al., 2008). At later stages of a persisting allergic immune response, also other $\mathrm{T}_{\mathrm{H}}$ subsets, e.g., $\mathrm{T}_{\mathrm{H}} 1$ and $\mathrm{T}_{\mathrm{H}} 17$, may be activated leading to an increased production of pro-inflammatory cytokines, such as IFN $\gamma$ and $\mathrm{TNF} \alpha$, or the $\mathrm{T}_{\mathrm{H}} 17$ cytokine IL-17 (reviewed in Holgate and Polosa, 2008).

There is increasing evidence that allergic reactions might influence immune status and functions of the CNS. In a rodent model of allergic rhinitis, reduced social interaction and anxiety-like behavior were observed, accompanied by the induction of a $\mathrm{T}_{\mathrm{H}}$ 2-biased cytokine mRNA profile (IL4 , IL-5, IL-13) in the olfactory bulb (OB) and the prefrontal cortex (Tonelli et al., 2009). In another model of airwayinduced allergy, the allergic reaction was associated with increased levels of the immunoglobulins IgG and $\operatorname{IgE}$ in CNS tissue, and with enhanced tau phosphorylation (Sarlus et al., 2012), a risk factor for the development of Alzheimer's disease (AD). Chronic airway-induced allergy in mice modifies gene expression in the brain toward insulin resistance and inflammatory responses (Sarlus et al., 2013). In mice, in which a food allergy was induced shortly after weaning, reduced social behavior, increased self-grooming, reduced alternation in the $\mathrm{T}$ maze as well as decreased dopamine levels in the prefrontal cortex were observed (de Theije et al., 2014). Another study in juvenile mice, which were exposed to a longterm OVA-based asthma regime, showed impaired learning and memory in the Morris water maze, disturbed long-term potentiation in the hippocampal CA1 region and reduced cell proliferation in the hippocampal neurogenic niche (Guo et al., 2013).

There are only few findings suggesting that allergic reactions, like allergic rhinitis and asthma, affect cognitive functions in humans. Individuals suffering from seasonal allergic rhinitis, for example, perform worse in cognitive tests (Hartgerink-Lutgens et al., 2009). Moreover, there is a positive correlation between allergic rhinitis and mood disorders, such as anxiety and depression (reviewed in Sansone and Sansone, 2011). Similarly, children with asthma have higher rates of depression, behavioral disorders, and learning disabilities (Blackman and Gurka, 2007; Blackman and Conaway, 2012). There is also a correlation between allergies and epilepsy in children (Silverberg et al., 2014). While elderly asthma patients can profit from anti-asthmatic treatment, at least temporarily, with improved cognitive functions (Bozek et al., 2010), patients suffering from seasonal allergic rhinitis have a slower processing speed during attention tasks-also during symptom-free periods (Trikojat et al., 2015).

While there are indications that chronic systemic inflammation might contribute to neurodegenerative diseases (reviewed in Perry, 2010; Czirr and Wyss-Coray, 2012; Cunningham, 2013), the data about a possible influence of allergy on neurodegeneration is still conflicting. A longitudinal study in a population-based twin sample showed a positive association between a history of atopy and dementia (Eriksson et al., 2008). However, another study reported recently that $\mathrm{AD}$ patients who also suffered from allergies had an improved biomarker profile, closer resembling that of healthy subjects (i.e., higher $A \beta_{42}$ levels in the cerebrospinal fluid), and had a better cognitive performance, which might indicate a beneficial effect of allergy on $\mathrm{AD}$ (Sarlus et al., 2015).

There is accumulating evidence that the immune system, e.g., via cytokines and chemokines, strongly modulates CNS functions like learning and memory, and also adult neurogenesis, the generation of new neurons in the adult CNS (reviewed in Yirmiya and Goshen, 2011). Thus, the aim of the present study was to investigate if an allergic reaction influences the hippocampus, specifically the dentate gyrus, which contains one of two classical neurogenic niches in the adult CNS and which is known for its central role in cognitive functions (reviewed in Marín-Burgin and Schinder, 2012; Bond et al., 2015). In comparison, we also analyzed the subventricular zone (SVZ), from which neuronal progenitors migrate via the rostral migratory stream to the $\mathrm{OB}$ to integrate into the neuronal networks, the second classical neurogenic niche (reviewed in Bond et al., 2015).

Based on these data, we hypothesized that a systemic allergic reaction affects neurogenesis and microglia in the hippocampus. Further, we expected that the effect of a $\mathrm{T}_{\mathrm{H}} 2$-polarized allergic response on microglial activation might differ from the well described reaction to a systemic LPS challenge.

\section{MATERIALS AND METHODS}

\section{Animals}

Female C57BL/6 mice (aged 10-12 weeks) were purchased from Charles River Germany and afterwards kept under standard animal housing conditions with free access to food and water at the animal facility at the University of Salzburg, Austria. All experimental procedures were approved by the Austrian Ministry of Science and carried out in compliance with International Ethical guidelines.

\section{Allergy Induction}

Recombinant Phl p 5.0101 (Phl p 5) was purchased from Biomay AG. The animals were divided into two groups: controls $(n=9)$ and allergy model $(n=10)$. The control group received all treatments using only the vehicle solution 
(phosphate-buffered saline, PBS). Animals of the allergy group were immunized intraperitoneally (i.p.) with $1 \mu \mathrm{g}$ Phl p 5 adjuvanted with $\mathrm{Al}(\mathrm{OH})_{3}$ (Alu-Gel-S from Serva) in PBS $(50 \%$ v/v, total volume: $200 \mu \mathrm{l}$ ) at weeks 1, 2, and 7. In week 11, starting 4 days before the perfusion (day 75), this group was challenged three times with a daily dose of $5 \mu \mathrm{g}$ Phl p 5 in $40 \mu \mathrm{l}$ PBS intranasally (i.n.; on days 71, 74 and 75). During this procedure, all mice (also the controls) were briefly anesthetized with isoflurane.

\section{Analysis of Blood Parameters}

Blood samples were taken at the end of the experiment (day 75), and incubated for $1 \mathrm{~h}$ at $37^{\circ} \mathrm{C}$. After centrifugation $(10 \mathrm{~min})$, the sera were collected and stored at $-80^{\circ} \mathrm{C}$ until measurements. Serum levels of Phl p 5-specific IgG1 and IgG2c were determined by a luminescence-based ELISA, and biologically functional IgE was measured in vitro by a rat basophil leukemia (RBL) cell assay. Additionally, cytokines, chemokines and the growth factor VEGF $\alpha$ were measured with a Luminex Multiplex Assay (Milliplex MAP Mouse Cytokine/Chemokine Magnetic Bead Panel, Merck) according to the manufacturer's instructions.

\section{Luminescence-Based ELISA Assay to Analyze Serological IgG Levels}

Levels of Phl p 5-specific IgG1 and IgG2c were determined using a luminescence-based ELISA assay as previously described (Weinberger et al., 2013). In short, 96-well plates for immunoassays (Greiner) were coated for $24 \mathrm{~h}$ at $4^{\circ} \mathrm{C}$ with recombinant Phl p 5 (per well $50 \mu \mathrm{l}$ of $1 \mu \mathrm{g} / \mathrm{ml} \mathrm{Phl}$ p 5 in PBS). Afterwards, plates were washed with $0.1 \%$ Tween-20 in PBS (v/v) and incubated with blocking buffer $(0.1 \%(\mathrm{v} / \mathrm{v})$ Tween 20 and 2\% (w/v) skim milk in PBS, $\mathrm{pH}$ 7.5) for $1 \mathrm{~h}$ at RT, before washing the plates again. Then, the plates were incubated with serum diluted $(1: 10,000)$ in blocking buffer for $1 \mathrm{~h}$ at RT, washed again, before the horse radish peroxidase (HRP)-conjugated antibodies for the detection of IgG1 (Zymed) or IgG2c (Zymed; diluted 1:1000 in blocking buffer) were added to the wells for $1 \mathrm{~h}$ at RT. After that, the luminometric assay (BM chemiluminescence substrate, Roche) was developed by adding the substrate (luminol diluted 1:2 in $\mathrm{H}_{2} \mathrm{O}$ ) to each well. After 3 min incubation, chemiluminescence (photon counts/s) was determined using an Infinite M200 Pro Plate Reader (Tecan).

\section{RBL Cell Assay to Measure Biologically Functional IgE}

The serum level of IgE was measured using a RBL cell assay as previously described (Weinberger et al., 2013). Briefly, RBL-2H3 cells (ATCC CRL-2256) were seeded in 96-well culture plates (Greiner) at a density of $6 \times 10^{5}$ cells $/ \mathrm{ml}$ and grown over night in $100 \mu \mathrm{l}$ culture medium per well at standard culture conditions $\left(37^{\circ} \mathrm{C}, 95 \%\right.$ relative humidity, $\left.5 \% \mathrm{CO}_{2}\right)$. The culture medium was RPMI 1640 supplemented with 10\% (v/v) heatinactivated fetal calf serum, $100 \mathrm{U} / \mathrm{ml}$ penicillin and $100 \mu \mathrm{g} / \mathrm{ml}$ streptomycin, $4 \mathrm{mM}$ L-glutamine, $2 \mathrm{mM}$ sodium pyruvate, 10 mM HEPES, and $100 \mu \mathrm{M} 2$-mercaptoethanol. Next day, cells were incubated for $2 \mathrm{~h}$ with different serum dilutions (1:50, 1:100, and 1:200). Untreated wells were used to assess background and maximum release values. To remove unbound antibodies, plates were washed twice with $200 \mu \mathrm{l}$ Tyrode's buffer $(137 \mathrm{mM} \mathrm{NaCl}$, $2.7 \mathrm{mM} \mathrm{KCl}, 0.5 \mathrm{mM} \mathrm{MgCl}_{2}, 1.8 \mathrm{mM} \mathrm{CaCl}_{2}, 0.4 \mathrm{mM} \mathrm{NaH}_{2} \mathrm{PO}_{4}$, $5.6 \mathrm{mM}$ D-glucose, $12 \mathrm{mM} \mathrm{NaHCO}_{3}, 10 \mathrm{mM}$ HEPES, and $0.1 \%$ $(\mathrm{w} / \mathrm{v})$ bovine serum albumin (BSA); $\mathrm{pH}$ 7.2). Then the cells were incubated for $30 \mathrm{~min}$ in $100 \mu \mathrm{l}$ of $0.1 \mu \mathrm{g} / \mathrm{ml}$ recombinant $\mathrm{Phl} \mathrm{p} 5$ diluted in Tyrode's buffer to induce crosslinking of FceR-bound IgE and degranulation of RBL cells. To determine maximum release, cell membranes were disrupted by adding $10 \mu \mathrm{l}$ of a $10 \%(\mathrm{v} / \mathrm{v})$ Triton X-100 solution. After that, $50 \mu \mathrm{l}$ of the cell culture supernatants were transferred into fresh 96-well plates (Greiner), where they were incubated for $1 \mathrm{~h}$ with $50 \mu \mathrm{l}$ assay solution at a final concentration of $80 \mu \mathrm{M} 4$-methylumbelliferyl $\mathrm{N}$-acetyl-b-D-glucosaminide (4-MUG, Sigma) in $0.1 \mathrm{M}$ citrate buffer ( $\mathrm{pH}$ 4.5). To stop the reaction, $100 \mu$ l glycine buffer (0.2 $\mathrm{M}$ glycine and $0.2 \mathrm{M} \mathrm{NaCl}, \mathrm{pH}$ 10.7) were added and fluorescence (in relative fluorescence units) was measured in a fluorescence microplate reader (Infinite M200 Pro, Tecan). Background values were subtracted from all measured values, and the results were presented as percentage of the maximum release value.

\section{Detection of Proliferating Cells to Determine Cell Fate}

For the detection of proliferating cells, a solution of $10 \mathrm{mg} / \mathrm{ml}$ bromodeoxyuridin (BrdU; Sigma-Aldrich) in $0.9 \% \mathrm{NaCl}(\mathrm{w} / \mathrm{v})$, in a dosage of $50 \mathrm{mg} / \mathrm{kg}$ body weight, was once injected i.p. in week 7 on day 47 ( 4 weeks before the end of the experiment).

\section{Bronchoalveolar Lavage (BAL) and Tissue Processing}

In week 11, mice were deeply anaesthetized by i.p. injection of a mixture of ketamine (273 $\mathrm{mg} / \mathrm{kg}$ body weight), xylazine (71 $\mathrm{mg} / \mathrm{kg}$ body weight) and acepromazine $(4 \mathrm{mg} / \mathrm{kg}$ body weight) in a physiological $\mathrm{NaCl}$ solution. During deep anesthesia (which was carefully evaluated), tracheotomy and a bronchoalveolar lavage (BAL) were performed. In short, the lungs were washed twice with $1 \mathrm{ml}$ of ice cold PBS and the fluid was collected back into the syringe. This BAL fluid was stored on ice until flow cytometric analysis (FACS Canto II, BD Bioscience).

After BAL, mice were transcardially perfused, first with a $0.9 \% \mathrm{NaCl}(\mathrm{w} / \mathrm{v})$ solution, and then with phosphate-buffered $4 \%$ paraformaldehyde ( $\mathrm{pH}$ 7.4). Afterwards, brains were removed, postfixed overnight in $4 \%$ paraformaldehyde, cryoprotected in phosphate-buffered $30 \%$ sucrose (w/v), and sectioned on dry ice with a sliding microtome. The sections (thickness: $40 \mu \mathrm{m}$ ) were stored at $-20^{\circ} \mathrm{C}$ in a cryoprotection solution (made of equal parts glycerin, 0.2 $\mathrm{M}$ phosphate buffer, ethylene glycol and $\mathrm{H}_{2} \mathrm{O}$ ).

\section{Analysis of the BAL Fluid}

BAL samples were centrifuged $\left(7 \mathrm{~min}, 250 \times \mathrm{g}, 4^{\circ} \mathrm{C}\right)$ and $450 \mu \mathrm{l}$ of supernatants were taken and mixed with $50 \mu \mathrm{l}$ of $10 \%$ BSA and $1 \% \mathrm{NaN}_{3}$ in $\mathrm{H}_{2} \mathrm{O}$ and frozen at $-80^{\circ} \mathrm{C}$. Cytokine levels in 
the BAL fluid were analyzed using a Luminex Multiplex Assay (MILLIPLEX MAP Mouse Cytokine/Chemokine Magnetic Bead Panel, Merck) according to the manufacturer's instructions.

For analysis of different immune cell populations in the BAL fluid, cell pellets were re-suspended in $100 \mu \mathrm{l}$ of the remaining supernatant and transferred into a 96-well V-bottom plate (Greiner), and then centrifuged $\left(5 \mathrm{~min}, 250 \times \mathrm{g}, 4^{\circ} \mathrm{C}\right)$. After that, cell pellets were re-suspended in $30 \mu \mathrm{l}$ antibody staining mix: CD45-PerCP/Cy5.5 (1:400, 30-F11, Biolegend), CD4BV421 (1:200, GK1.5, Biolegend), CD19-PE-Cy7 (1:100, 6D5, Biolegend), Gr-1-APC (1:200, RB6-8C5, eBioscience), Siglec-FPE (1:200, E50-2440, BD Biosciences), CD8-FITC (1:100, 536.7, eBioscience) and incubated for $10 \mathrm{~min}$ on ice. Afterwards, the cells were washed with $100 \mu \mathrm{l}$ FACS buffer $(0.5 \%$ BSA and $2 \mathrm{mM}$ EDTA in PBS), and then incubated for $5 \mathrm{~min}$ at $\mathrm{RT}$ in $100 \mu$ l Red Blood Cell (RBC) Lysis Buffer (eBioscience) to remove residual RBCs. After another washing step (using FACS buffer), cell pellets were re-suspended in $120 \mu$ FACS buffer and transferred into FACS tubes. Cells were analyzed on a FACS Canto II flow cytometer (BD Bioscience) and data were recorded for $30 \mathrm{~s}$ at a rate of $120 \mu \mathrm{l} / \mathrm{min}$ to calculate the absolute cell numbers per BAL. For flow cytometric analysis, at first total leukocytes were gated based on their expression of CD45. The FSC/SSC plots were used to exclude cell debris, and then in FSC-W/FSC-A plots the single cells were gated. Neutrophils were identified based on their high Gr1 expression. The other cells were gated according to their expression of CD4, CD8, and SiglecF. SiglecF is highly expressed on eosinophils and monocytes. Monocytes were then separated from eosinophils by their autofluorescence in the BV-510 channel. In general, the observed CD19 staining was weak; therefore, $\mathrm{CD} 19^{+}$cells were identified after exclusion of the previously gated cell types.

\section{Immunohistochemistry}

Immunohistological stainings were performed as previously described (Kandasamy et al., 2014), using the following antibodies and dilutions. Primary antibodies: rat anti-BrdU (1:500, BU1/75, AbD Serotec), rabbit anti-CD68 (1:500, ab125212, Abcam), rabbit anti-doublecortin (1:250, 4604, Cell Signaling), guinea pig anti-GFAP (1:500, GP52, Progen), rabbit anti-Ibal (1:300, 019-19741, Wako), goat anti-Ibal (1:250, ab107159, Abcam), anti-mouse MHCII (I-A/I-E; 1:100, 145321-82, eBioscience), mouse anti-NeuN (1:500, A60, Merck Millipore), mouse anti-PCNA (1:500, sc-56, Santa Cruz). Secondary antibodies: donkey anti-rat Alexa 488, donkey anti-goat, -mouse Alexa 568, donkey anti-rabbit, -guinea pig Alexa 647 (all 1:1000, Invitrogen, Life technologies), donkey anti-rat Cy5, donkey anti-mouse biotinylated (1:1000, Jackson Immuno Research), goat anti-rabbit biotinylated, rabbit anti-rat biotinylated (all 1:500, Vector Labs). Cell nuclei were stained with $4^{\prime}, 6$-diamidino-2-phenylindole dihydrochloride at a concentration of $0.5 \mu \mathrm{g} / \mu \mathrm{l}$ (DAPI; Sigma-Aldrich).

Image documentation and analysis were done using a Zeiss Axioplan light microscope or a confocal scanning laser microscope (Zeiss LSM 700) with LSM Software (ZEN 2012) for fluorescent stainings.

\section{Quantitative Analysis of Immunohistological Stainings}

Image acquisition and quantification were done blinded (i.e., without knowing group or mouse number). For quantitative analysis, a representative tenth of one brain hemisphere was analyzed by collecting every 10th section, with an interval of $400 \mu \mathrm{m}$ between sections. This 10th of a hemisphere was used for immunohistochemistry with a chromogenic dye. The total number of stained cells within the regions of interest was counted using a Zeiss Axioplan light microscope. In the dorsal hippocampal dentate gyrus, the total numbers of $\mathrm{PCNA}^{+}, \mathrm{BrdU}^{+}, \mathrm{Iba}^{+}$and $\mathrm{DCX}^{+}$cells were counted. In addition, the total number of $\mathrm{BrdU}^{+}$cells in the SVZ was determined.

To investigate the cell fate of $\mathrm{BrdU}^{+}$cells in the dorsal dentate gyrus, a BrdU/NeuN/GFAP fluorescence staining was analyzed. For each animal, z-stacks of the dorsal dentate gyrus were made in a 10th brain hemisphere on a Zeiss LSM 700 laser scanning microscope. In these image stacks all $\mathrm{BrdU}^{+}$cells were counted, and at the same time, it was also determined if these cells were co-labeled for NeuN or GFAP. Thus, the percentage of $\mathrm{BrdU}^{+} \mathrm{NeuN}^{+}$or $\mathrm{BrdU}^{+} \mathrm{GFAP}^{+}$cells was determined per animal. Similarly, $\mathrm{BrdU}^{+}$cells in the granular cell layer of the $\mathrm{OB}$ were analyzed in a region of $400 \times 400 \times 40 \mu \mathrm{m}$.

To analyze the activation state of $\mathrm{Ibal}^{+}$cells in the dorsal dentate gyrus, the numbers of $\mathrm{Iba}^{+} \mathrm{MHCII}^{+}$and $\mathrm{Iba}^{+}{ }^{+} \mathrm{CD} 68^{+}$ cells were counted in $\mathrm{Z}$-stacks (generated using a with Zeiss LSM 700 equipped with the Zeiss ZEN 2012 software) of four visual fields $(400 \times 400 \times 40 \mu \mathrm{m})$ per animal. For the OB, one visual field of the granular cell layer was analyzed.

To estimate the analyzed volume for each region, the corresponding tissue area in the middle of the stack was measured and then multiplied by $40 \mu \mathrm{m}$. Then the cell densities were determined by dividing the total number of counted cells by this volume and presented as cells $/ \mathrm{mm}^{3}$.

\section{Statistics}

Data are shown as Mean + standard deviation (SD). Statistical significance was determined in Prism 5 (Graphpad Software Inc) using independent samples $t$-tests (the corresponding $p$-values are represented as: $\left.{ }^{*} p<0.05,{ }^{* *} p<0.01,{ }^{* * *} p<0.001\right)$. To adjust for multiple comparisons between the two groups, we computed for each large family of comparisons (cytokines in serum, cytokines in BAL fluid, and cell types in BAL fluid) a Holm-Šídák correction for multiple $t$-tests (at a global alpha level of 0.05) and reported the multiplicity adjusted $p$-values (in brackets) in addition to the unadjusted $p$-values. Statistical outliers were identified using the Grubb's test $(p<0.05)$ in the QuickCals GraphPad Software ${ }^{1}$.

\footnotetext{
${ }^{1}$ http://graphpad.com/quickcalcs/grubbs1.
} 


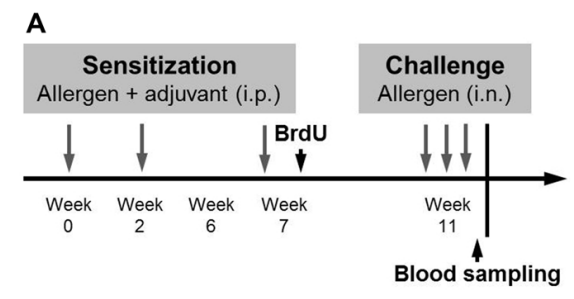

D

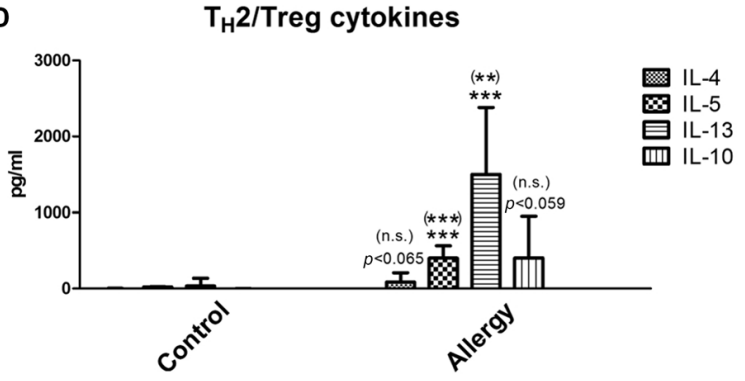

F

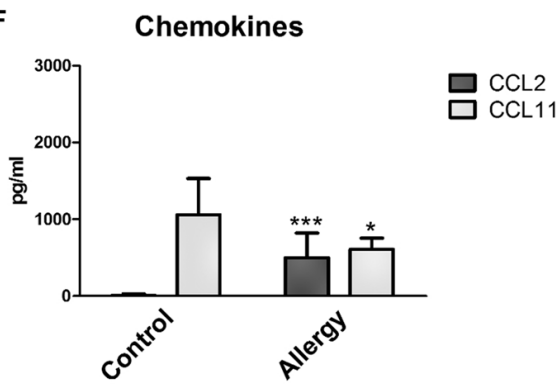

B
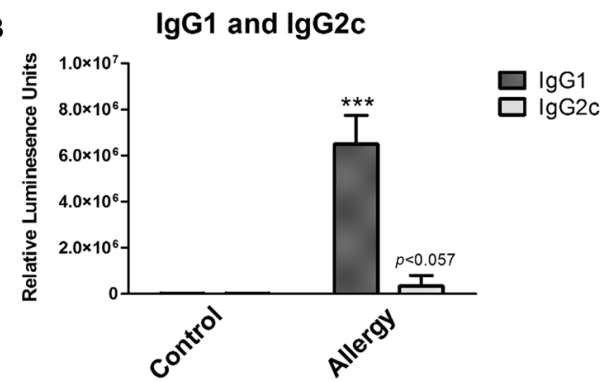

C

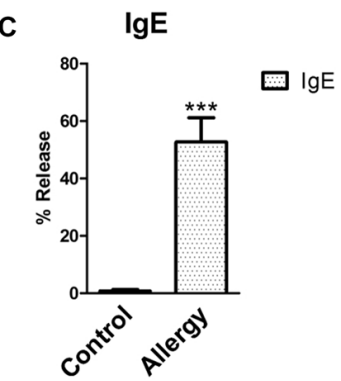

E

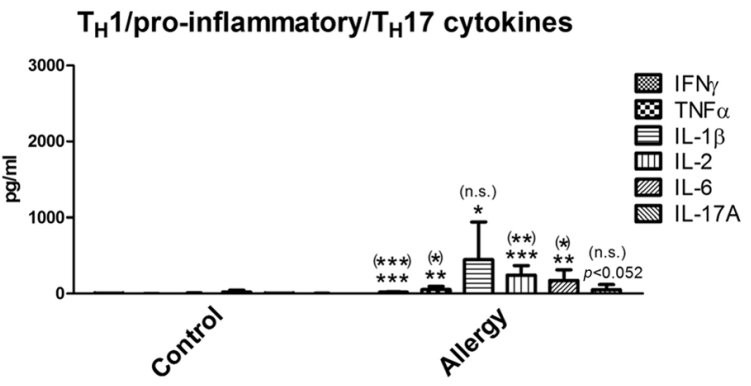

$\mathbf{G}$

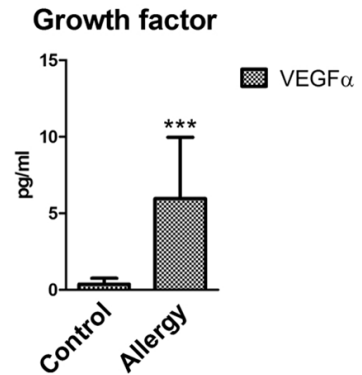

FIGURE 1 | Experimental design and serological analysis. (A) Setup of the experiment. (B-D) Serological changes in Phl p 5-sensitized and rechallenged mice confirmed a $T_{H} 2$-polarized immune response. At the end of the experiment, sera were analyzed for (B) Phl p 5-specific lgG1 and lgG2C, and (C) biologically functional IgE. (D) Serum levels of $T_{H} 2$ cytokines (IL-4, IL-5 and IL-13) and the $T_{H} 2 / T_{r e g}$ cytokine IL-10. (E) Serum levels of $T_{H} 1 /$ pro-inflammatory cytokines (IFN $\gamma$, TNF $\alpha, I L-1 \beta, I L-2, I L-6)$ and the $T_{H} 17$ cytokine IL-17A. (F) Levels of the chemokines CCL2 and CCL11 and of (G) the growth factor VEGF $\alpha$ in the serum. Data are shown as Mean + SD. (control: $n=9$, allergy: $n=10)$. Statistical significance was determined using independent samples $t$-tests $\left({ }^{*} p<0.05\right.$, ${ }^{* *} p<0.01$, ${ }^{* * *} p<0.001$; n.s. - not significant), multiplicity adjusted $p$-values (Holm-Šídák correction for multiple $t$-tests) are reported in brackets $((*) p<0.05$, $(* *) p<0.01$, $(* * *) p<0.001 ;$ (n.s.) - not significant).

\section{RESULTS}

\section{Allergic Mice Have a $\mathrm{T}_{\mathrm{H}}$ 2-polarized Immune Reaction}

The allergen used in the present study, Phl p 5, is derived from timothy grass pollen and frequently responsible for allergy symptoms in human patients (Matthiesen and Løwenstein, 1991; Sekerkova et al., 2012). After sensitization, lung inflammation was induced in $\mathrm{C} 57 \mathrm{BL} / 6$ mice via intranasal application of the allergen (experimental set-up see Figure 1A). To exclude that any of the observed effects were caused by experimental procedures (e.g., handling of the animals or anesthesia), the controls underwent all experimental steps at the same time as the allergy group and received the vehicle solution (PBS) during sensitization and challenge.

First, the allergic status of the sensitized mice was confirmed by measuring blood and lung parameters. For this, the levels of allergen-specific immunoglobulins were determined. In mice, the $\mathrm{T}_{\mathrm{H}} 2$ cytokine IL- 4 is necessary for the immunoglobulin class switch to IgG1 and IgE, whereas the $\mathrm{T}_{\mathrm{H}} 1$ cytokine IFN $\gamma$ would cause a class switch to IgG2c. Thus, the immunoglobulin measurements (Figures 1B,C) showed that mice sensitized to the allergen had a $\mathrm{T}_{\mathrm{H}} 2$ polarized immune response, since we observed high IgG1 (Figure 1B) and IgE (Figure 1C) levels, whereas IgG2c was not significantly elevated in comparison to controls (Figure 1B). 

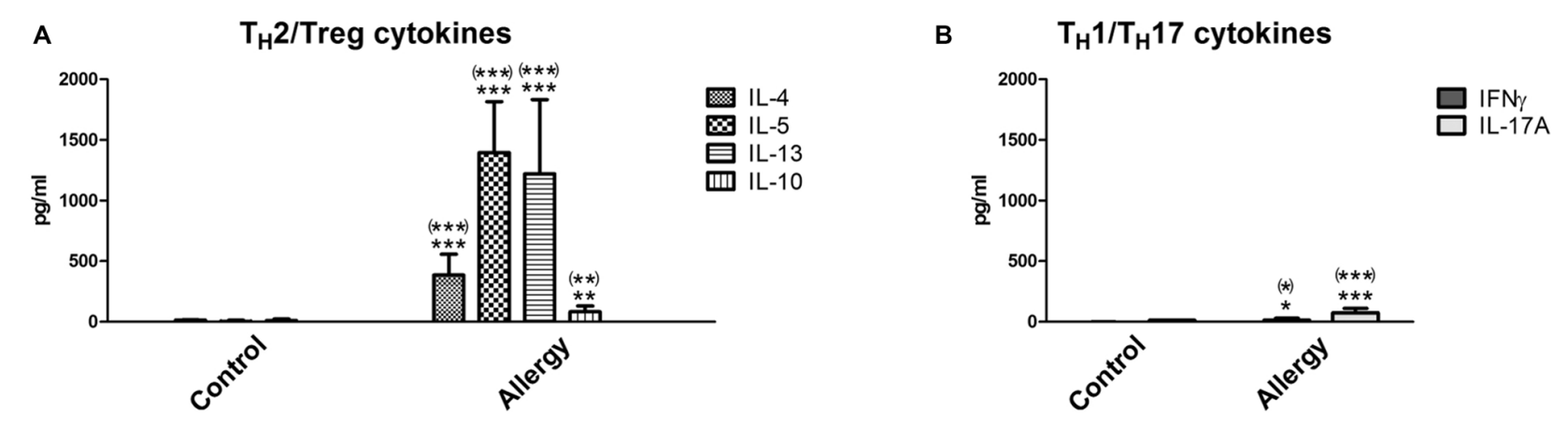

C

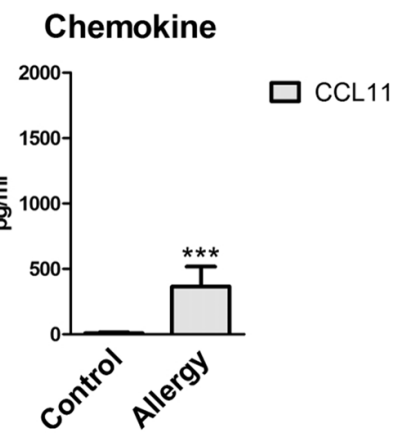

D

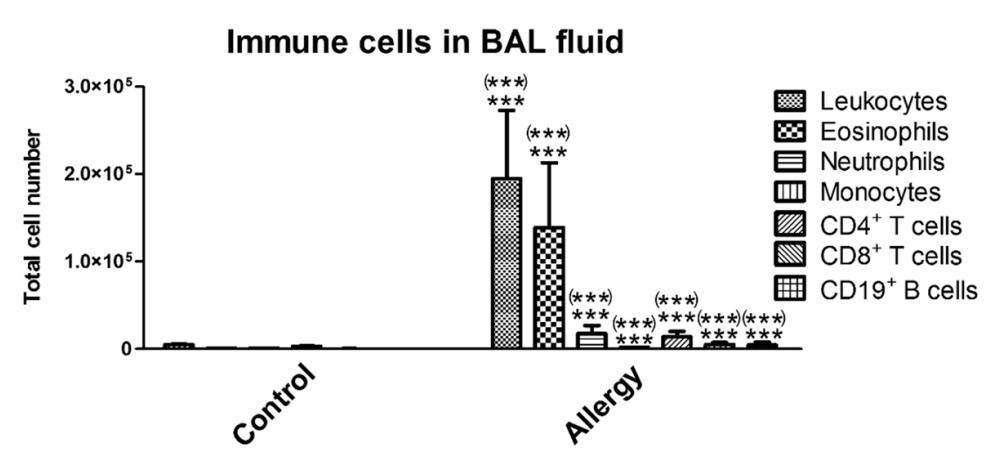

FIGURE 2 | Cytokines and immune cells in bronchoalveolar lavage (BAL) fluid. Analysis of immune parameters in the BAL fluid confirmed a $T_{H} 2-$ polarized immune reaction in the lungs of allergic mice. (A) BAL fluid levels of $T_{H} 2$ cytokines (IL-4, IL-5, and IL-13) and the $T_{H} 2 / T_{r e g}$ cytokine IL-10. (B) BAL fluid levels of the $\mathrm{T}_{H} 1$ cytokine IFN $\gamma$, the $T_{H} 17$ cytokine IL-17A, and $(\mathbf{C})$ the chemokine CCL11. (D) Immune cells which infiltrated into the lungs were analyzed in the BAL fluid using flow cytometry. Leukocytes, eosinophils, neutrophils, monocytes, T cells (CD4 ${ }^{+}$or CD8 ${ }^{+}$) and CD19+ B cells were detected. Data are shown as Mean + SD. (control: $n=9$, allergy: $n=10)$. Statistical significance was determined using independent samples $t$-tests $\left({ }^{*} p<0.05\right.$, ${ }^{* *} p<0.01,{ }^{* * *} p<0.001$; n.s. - not significant), multiplicity adjusted $p$-values (Holm-Šídák correction for multiple $t$-tests) are reported in brackets $\left(\left(^{*}\right) p<0.05,\left({ }^{* *}\right) p<0.01\right.$, $\left({ }^{* * *}\right) p<0.001$; n.s. - not significant).

As expected, high serum levels of $\mathrm{T}_{\mathrm{H}} 2$ cytokines IL-5 and IL-13 were observed in the allergy model (Figure 1D). The $\mathrm{T}_{\mathrm{H}} 2$ cytokine IL-4 was also modestly, but not significantly, elevated in the allergy model in comparison to controls. The cytokine IL-10 (Figure 1D), which can be derived from $\mathrm{T}_{\mathrm{H}} 2$ but also from regulatory Tr1 cells, was not significantly increased in allergic mice. Additionally, we found a modest increase of the proinflammatory cytokines IFN $\gamma, \mathrm{TNF} \alpha$, IL- $1 \beta$, IL-2 and IL-6 in the sera of allergic mice (Figure 1E). Also, the serum levels of the $\mathrm{T}_{\mathrm{H}} 17$ cytokine IL-17A were slightly, but not significantly, elevated in the allergy model (Figure 1E).

The chemokine CCL2, which is an effective attractant for monocytes, was significantly increased in the allergy model, whereas surprisingly CCL11, a signaling molecule attracting eosinophils was significantly decreased in the serum of allergic mice (Figure 1F). The growth factor VEGF $\alpha$ was also increased in the allergy model (Figure 1G).

In the lungs of the allergic mice similar changes were observed. In the BAL fluid, the levels of the typical $\mathrm{T}_{\mathrm{H}} 2$ cytokines (IL-4, IL-5 and IL-13) and of IL-10 were increased (Figure 2A). The $\mathrm{T}_{\mathrm{H}} 1$ cytokine $\mathrm{IFN} \gamma$ and the $\mathrm{T}_{\mathrm{H}} 17$ cytokine IL-17A were also slightly increased (Figure 2B). In contrast to the serum, the chemokine CCL11 was markedly elevated in the BAL fluid, which was expected since CCL11 is important for the recruitment of eosinophils (Figure 2C). Indeed, the number of infiltrating leukocytes and eosinophils was very high in the BAL fluid of allergic mice (Figure 2D). Also neutrophils, $\mathrm{T}$ cells $\left(\mathrm{CD} 4^{+}\right.$and $\left.\mathrm{CD}^{+}\right)$and $\mathrm{CD} 19^{+} \mathrm{B}$ cells invaded the lungs of the allergy model (Figure 2D). Unexpectedly, we found a small, but significant, reduction in the number of monocytes in the BAL fluid of allergic mice (Figure 2D).

\section{Allergy Modulates Microglia in the Hippocampal Neurogenic Niche}

The neurogenic niche of the hippocampus is located in the subgranular zone (SGZ) of the dentate gyrus. The neurons which are generated from the neural stem cells in the SGZ then integrate into the granular layer (GL) of the dentate gyrus (reviewed in Bond et al., 2015). Microglia, the tissue macrophages of the CNS, play an important part in regulating the neurogenic niche (reviewed in Kokaia et al., 2012; Sierra et al., 2014). Since these cells are especially reactive to immune signals from the periphery (Hoogland et al., 2015), we checked whether they are influenced by allergy using the marker Ibal which 
labels microglia and macrophages (Figure 3A). Surprisingly, a significant reduction in the number of $\mathrm{Iba}^{+}$cells was observed in allergic mice in the GL and SGZ of the dorsal hippocampal dentate gyrus (control: $2456 \pm 295$ cells per hemisphere, allergy: $1924 \pm 275$ cells per hemisphere; $p<0.0013$; Figure 3B).

To check if also other commonly used markers for microglial activation were altered in allergic mice, we quantified MHCII, which is important for antigen presentation, and CD68, which is associated with lysosomes. In both, controls and the allergy group, these markers were mainly found in intracellular compartments, presumably lysosomes or endosomes (Figure 3C). While significantly fewer $\mathrm{Iba}^{+}$cells also expressed MHCII in allergic mice (control: $7172 \pm 913$ cells $/ \mathrm{mm}^{3}$, allergy: $5555 \pm 766$ cells $/ \mathrm{mm}^{3} ; p<0.0001$; Figure 3D), there was no change in the numbers of $\mathrm{Iba}^{+} \mathrm{CD}^{+} 8^{+}$cells (control: $10103 \pm 609$ cells $/ \mathrm{mm}^{3}$, allergy: $10300 \pm 1002$ cells $/ \mathrm{mm}^{3}$; $p<0.6345$; Figure 3E).

\section{Allergy Activates Microglia in the Granular Cell Layer of the OB}

The $\mathrm{OB}$ is the brain region into which SVZ-derived newly generated neurons integrate (reviewed in Bond et al., 2015). Using the same markers as in the hippocampus, we analyzed microglial activation in the $\mathrm{OB}$ (Figure 4A) to find out if the changes we observed were specific for the hippocampus.

In contrast to the hippocampal neurogenic niche, allergy elevated the number of $\mathrm{Iba}^{+}$microglia in the granular cell layer of the OB (control: $9890 \pm 546$ cells $/ \mathrm{mm}^{3}$, allergy: $11271 \pm 985$ cells $/ \mathrm{mm}^{3} ; p<0.0027$ ) (Figure 4B). In parallel, also the numbers of $\mathrm{Ibal}^{+} \mathrm{MHCII}^{+}$cells (control: $8433 \pm 919$ cells $/ \mathrm{mm}^{3}$, allergy: $9829 \pm 915$ cells $/ \mathrm{mm}^{3} ; p<0.0060$ ) (Figure 4C) and of $\mathrm{Iba}^{+}{ }^{+} \mathrm{CD} 8^{+}$cells (control: $9370 \pm 638$ cells $/ \mathrm{mm}^{3}$, allergy $10676 \pm 1123$ cells $/ \mathrm{mm}^{3} ; p<0.0098$ ) (Figure 4D) increased. This indicates that allergy leads to more activated microglia in the OB.

\section{Allergy Increases the Number of Immature DCX ${ }^{+}$Neurons in the Hippocampus}

To investigate hippocampal neurogenesis in $\mathrm{Phl} \mathrm{p} \mathrm{5-sensitized}$ mice after re-exposure to the allergen, we first quantified total cell proliferation in the GL and SGZ of the dorsal dentate gyrus. The marker PCNA labeled cells which were proliferating shortly before the animals were sacrificed, i.e., during allergen challenge (Figure 5A). This analysis showed that the number of $\mathrm{PCNA}^{+}$proliferating cells in the dentate gyrus was not changed in the allergy model (control: $1579 \pm 223$ cells per hemisphere; allergy: $1606 \pm 179$ cells per hemisphere; $p<0.7847$; Figure 5B).

Next, we evaluated if there were changes in immature DCX-expressing neurons in the hippocampal neurogenic niche (Figure 5C). Indeed, allergic mice had an increased number of $\mathrm{DCX}^{+}$cells in the GL and SGZ of the dorsal dentate gyrus (control: $2659 \pm 337$ cells per hemisphere, allergy: $3395 \pm 591$ cells per hemisphere; $p<0.0064$; Figure 5D).
Taken together these results suggest that even though the proliferation rate at the end of the experiment was not changed, either more immature neurons were generated already earlier after the sensitization phase or the differentiation of $\mathrm{DCX}^{+}$cells was delayed.

\section{Allergy Increases Production of Mature Neurons $\left(\mathrm{BrdU}^{+} \mathrm{NeuN}^{+}\right)$in the Hippocampus}

For cell fate analysis, mice received a single injection of BrdU after the last sensitization step and 4 weeks before the end of the experiment. BrdU, a thymidine analog, incorporates into the DNA of proliferating cells. Thus, a $\mathrm{BrdU}^{+}$nucleus indicates a cell that had been dividing at the time of injection, i.e., after the sensitization was completed, and survived until the end of the experiment (Figure 6A). A quantification of the total number of $\mathrm{BrdU}^{+}$cells in the GL and SGZ of the dorsal dentate gyrus showed that the allergic mice had a significantly higher number of $\mathrm{BrdU}^{+}$cells than the control group (control: $206 \pm 40$ cells per hemisphere, allergy: $339 \pm 107$ cells per hemisphere; $p<0.0046$; Figure 6B).

Since the increase in $\mathrm{BrdU}^{+}$cells in the hippocampal GL and SGZ of allergic mice could not be explained by microglial cells, as their numbers actually decreased, we further analyzed the cell fate of these $\mathrm{BrdU}^{+}$cells and investigated if they became $\mathrm{NeuN}^{+}$ mature neurons or $\mathrm{GFAP}^{+}$astrocytes or radial glia (Figure 6C). In allergic mice, the number of $\mathrm{BrdU}^{+} \mathrm{NeuN}^{+}$mature neurons increased significantly (control: $1264 \pm 271$ cells $/ \mathrm{mm}^{3}$, allergy: $1766 \pm 382$ cells $/ \mathrm{mm}^{3} ; p<0.0065$; Figure 6D). There was also a slight, but not significant increase in the number of $\mathrm{BrdU}^{+} \mathrm{GFAP}^{+}$cells (control: $446 \pm 154 ; 566 \pm 211 ; p<0.2027$; Figure 6D). However, the percentages of $\mathrm{BrdU}^{+}$cells which were either positive for NeuN or GFAP were unchanged (Figure 6E).

These results indicate that the observed increase in $\mathrm{BrdU}^{+}$ cells is due to an increased net production of mature $\mathrm{NeuN}^{+}$ neurons in the hippocampal neurogenic niche and not caused by a change in the differentiation fate of the cells.

\section{Allergy Neither Affects the Numbers of BrdU+ Cells in the SVZ nor the Cell Fate of BrdU + Cells in the OB}

To assess if the pro-neurogenic effect of allergy was specific for the hippocampus, or if it was also affecting the other classical neurogenic niche, we analyzed $\mathrm{BrdU}^{+}$cells in the SVZ (Figures $7 \mathrm{~A}, \mathbf{B}$ ) and $\mathrm{OB}$ (Figures $7 \mathrm{C}-\mathbf{E}$ ). In the SVZ, in both groups, hardly any $\mathrm{BrdU}^{+}$cells were left (Figure 7A), and there was no significant difference between the groups (control: $76 \pm 33$ cells per hemisphere, allergy: $93 \pm 37$ cells per hemisphere; $p<0.3188$; Figure 7B). Next, we did an analysis of cell fate of $\mathrm{BrdU}^{+}$cells in the $\mathrm{OB}$ (Figures 7C-E). There was no significant difference in the densities of $\mathrm{BrdU}^{+}$cells between the groups (control: $9114 \pm 1425$ cells $/ \mathrm{mm}^{3}$, allergy: $9396 \pm 2105$ cells $/ \mathrm{mm}^{3}$; $p<0.7534$ ) and also the density of $\mathrm{BrdU}^{+} \mathrm{NeuN}^{+}$(control: $8059 \pm 1149$ cells $/ \mathrm{mm}^{3}$, allergy: $8216 \pm 1819$ cells $/ \mathrm{mm}^{3}$; 


\section{A}

\section{Control}

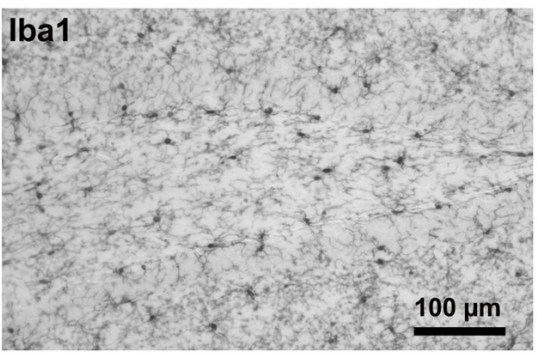

\section{Allergy}

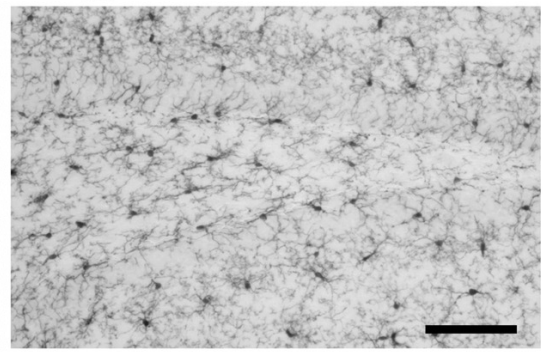

B

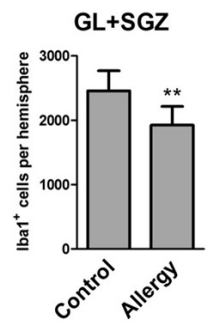

C

\section{Control}
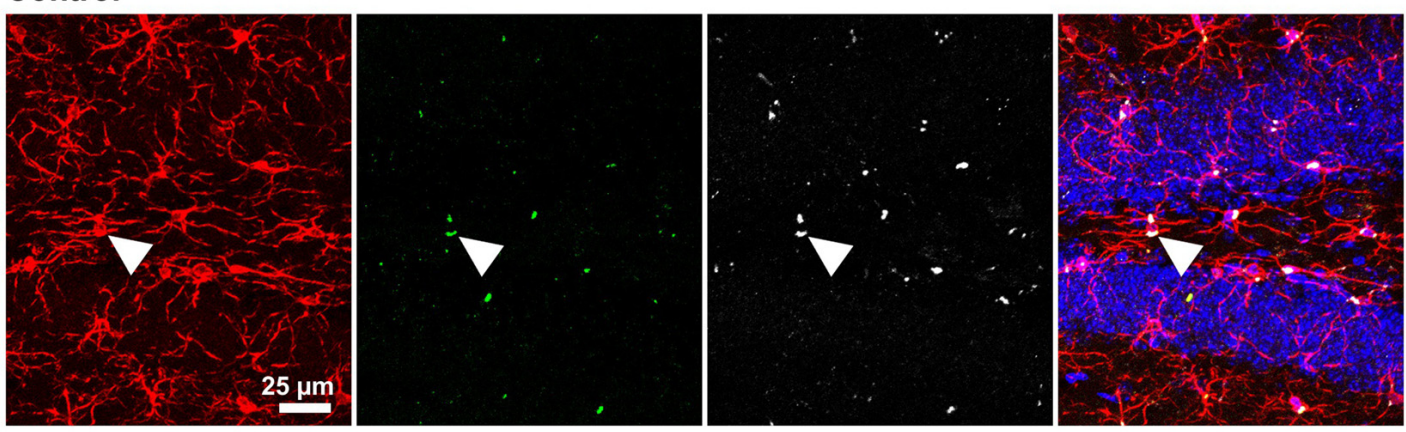

\section{Allergy}
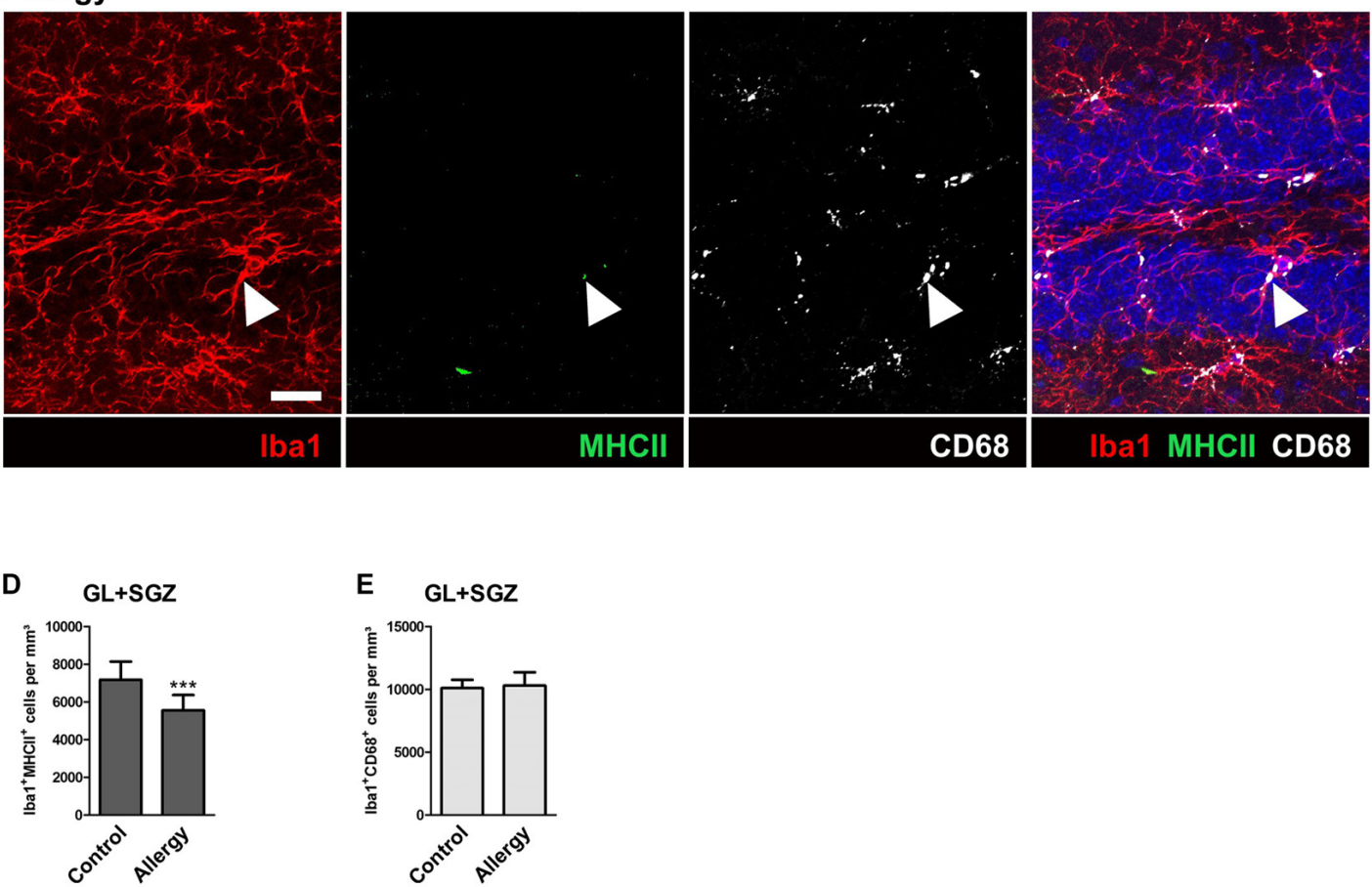

FIGURE 3 | Reduced numbers of lba1 ${ }^{+}$microglia and of microglia expressing MHCII in the hippocampal neurogenic niche of allergic mice. (A) lba1 ${ }^{+}$ microglia in the hippocampal dentate gyrus. (B) The number of lba1+ cells in the granular layer (GL) and subgranular zone (SGZ) of the dentate gyrus is lower in allergic mice than in controls (C) Triple labeling of lba1 (red), MHCIl (green) and CD68 (white). Cell nuclei are stained with DAPI (blue). Triple-positive cells are indicated by arrow heads. (D) The number of $\mathrm{lba1}{ }^{+} \mathrm{MHCll}^{+}$cells was decreased in the neurogenic niche of allergic mice, whereas (E) $\mathrm{Iba1}{ }^{+} \mathrm{CD} 68^{+}$cells were not affected. Values are depicted as Mean + SD. (control: $n=9$, allergy: $n=10$ ). Statistical significance was evaluated using independent samples $t$-tests and is indicated in comparison to the control group $\left({ }^{*} p<0.05,{ }^{* *} p<0.01,{ }^{* * *} p<0.001\right)$. Scale bars: (A) $100 \mu \mathrm{m}$, (C) $25 \mu \mathrm{m}$. 
A

\section{Control}
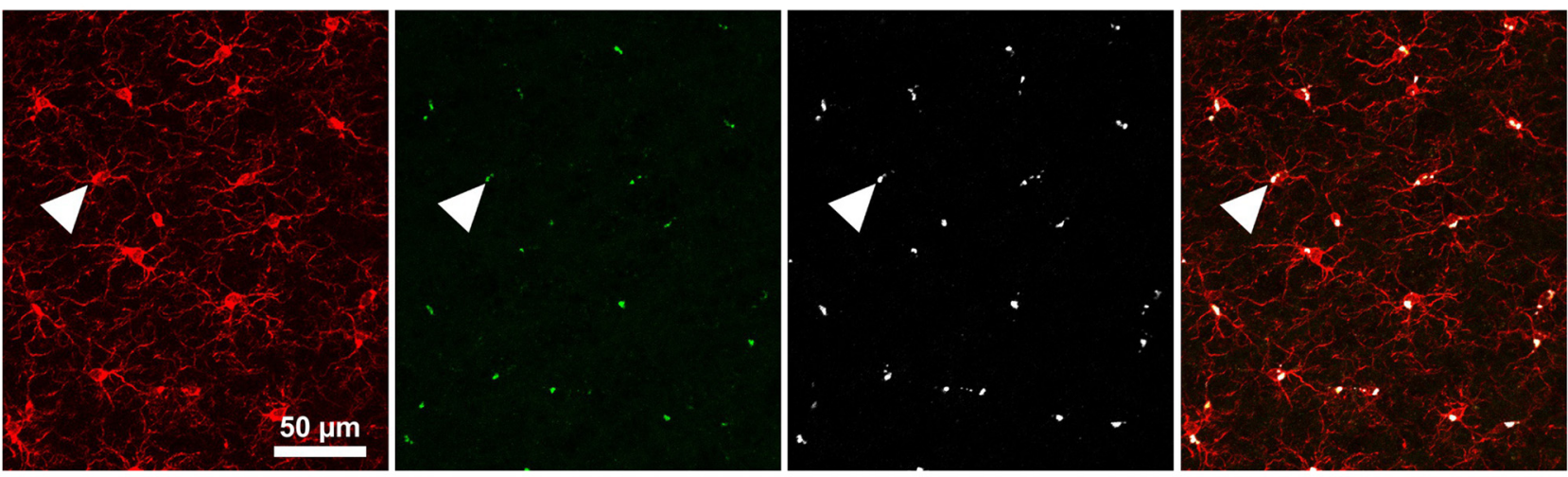

\section{Allergy}
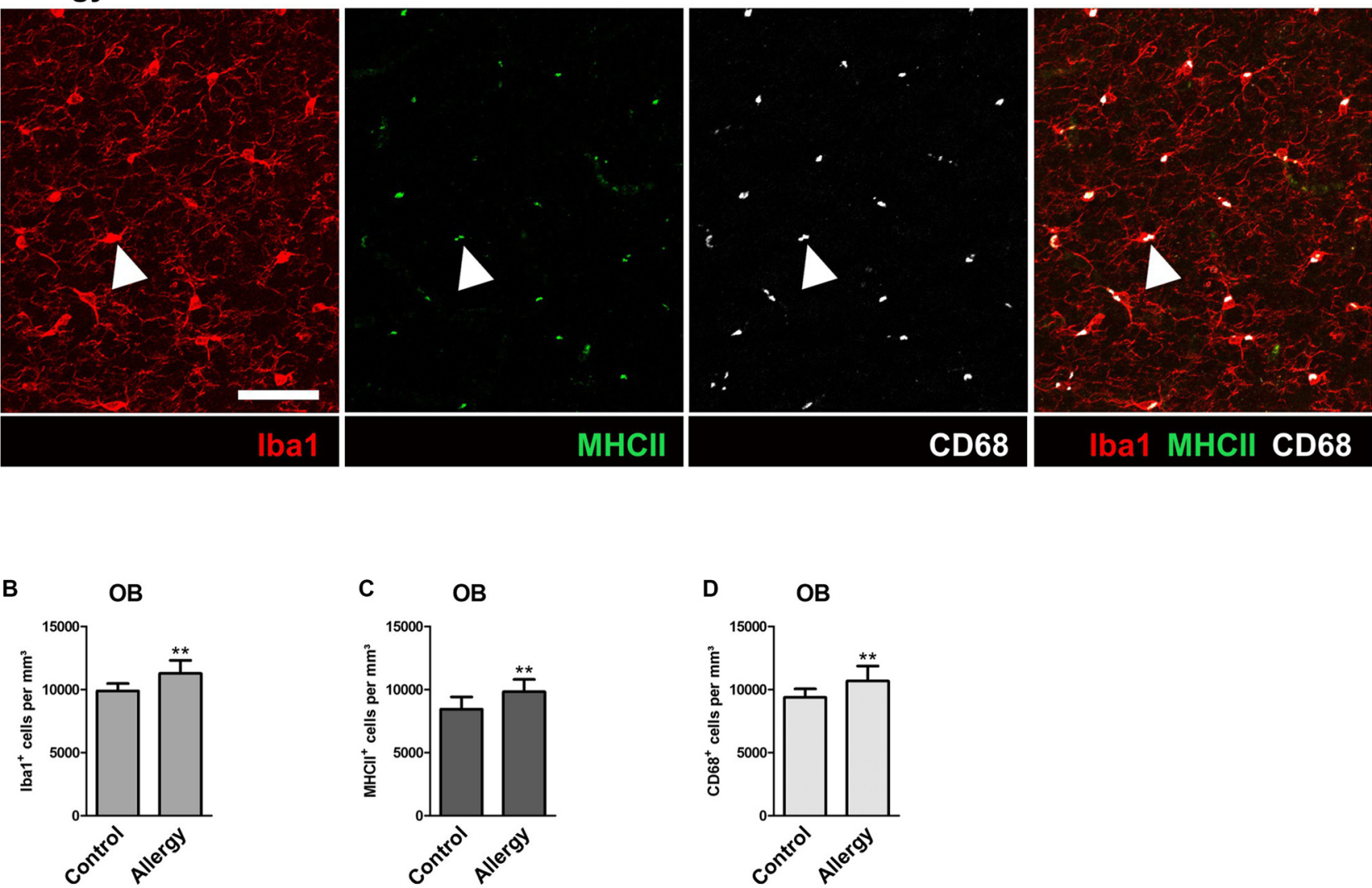

FIGURE 4 | Number of lba1 ${ }^{+} \mathbf{M H C I I}^{+}$and Iba1+ CD68 $^{+}$microglia is increased in the olfactory bulb (OB) of allergic mice. (A) Triple labeling of lba1 (red),

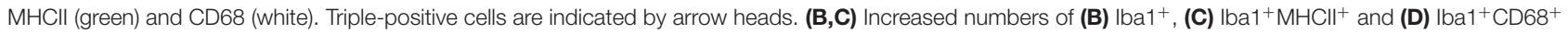
cells in the granular cell layer of the OB. Values are depicted as Mean + SD. (control: $n=9$, allergy: $n=10$ ). Statistical significance was evaluated using independent samples $t$-tests and is indicated in comparison to the control group $\left({ }^{*} p<0.05,{ }^{* *} p<0.01,{ }^{* * *} p<0.001\right)$. Scale bars: $50 \mu \mathrm{m}$.

$p<0.8363$ ) or $\mathrm{BrdU}^{+} \mathrm{GFAP}^{+}$cells (control: $889 \pm 355$ cells $/ \mathrm{mm}^{3}$, allergy: $990 \pm 451$ cells $\left./ \mathrm{mm}^{3} ; p<0.6178\right)$ did not change significantly (Figure 7D). In both cases, around 90\% of these $\mathrm{BrdU}^{+}$cells in the $\mathrm{OB}$ were also positive for NeuN (control: $88.6 \pm 2.9 \%$, allergy: $87.5 \pm 3.6 \%$; $p<0.4834$; Figure 7E).

\section{DISCUSSION}

In the present study, the effects of a $\mathrm{T}_{\mathrm{H}}$ 2-polarized systemic inflammation on the neurogenic niche in the hippocampus were analyzed in a model of grass pollen allergy. Surprisingly, allergy seems to have a positive impact on the production of new 
neurons and leads to a down-regulation of microglial activation in this region.

The analysis of immunological parameters in sera and lungs confirmed that in the allergy model a $\mathrm{T}_{\mathrm{H}} 2$-polarized allergic reaction was induced. As expected, the allergy model showed the typical immunoglobulin pattern for an allergic immune response (high levels of allergen-specific IgE and IgG1, low levels of IgG2c). In addition to a robust increase of $\mathrm{T}_{\mathrm{H}} 2$ cytokines in serum and BAL fluid, also a modest, but significant, induction of pro-inflammatory cytokines was observed. Moreover, CCL2 an important chemoattractant for monocytes was increased in the serum. These immune parameters are in line with what has been described for patients suffering from allergies affecting the airways (Kuna et al., 1996; Holgate et al., 1997).

Microglia are the tissue macrophages of the CNS and are responsible for CNS immune surveillance. They react to pathogenic events and are "activated" in a multi-step process (Kettenmann et al., 2011), which leads to an upregulation of specific proteins, e.g., MHCII for antigen-presentation or CD68 which is associated with lysosomes and endosomes (Boche et al., 2013). Microglia are also part of the hippocampal neurogenic niche, and have regulatory functions there (Gemma and Bachstetter, 2013; Sierra et al., 2014). The allergic immune response in our model affected these immune cells in the hippocampal neurogenic niche in an unexpected way: allergy led to a "deactivation" of microglia in this region, since both, their numbers and their MHCII expression were reduced.

Actually, there is one study showing that-in the absence of inflammatory stimuli-the rate of neurogenesis and microglial numbers, specifically in the dentate gyrus, are inversely correlated (Gebara et al., 2013). This fits to our results, since we observed an increase of neurogenesis accompanied by a reduction in microglial numbers ( $\mathrm{Iba1}^{+}$cells). The further reduction of microglia that are expressing MHCII (from $58.8 \pm 5.1 \%$ in controls to $44.7 \pm 4.6 \%$ in allergic mice, $p<0.00001$; data not shown) might suggest that the affected microglia were either less phagocytic or less inclined to present the phagocytosed antigens as MHCII is involved in this process. A reduced phagocytic activity could be explained by a lack of cellular debris due to an increased survival of newly generated immature $\mathrm{DCX}^{+}$neurons, since superfluous progenitors are normally phagocytosed by microglia (Sierra et al., 2010). However, the number of microglia expressing CD68, a widely used marker for microglial activation, which is located in phagosomes and lysosomes, was
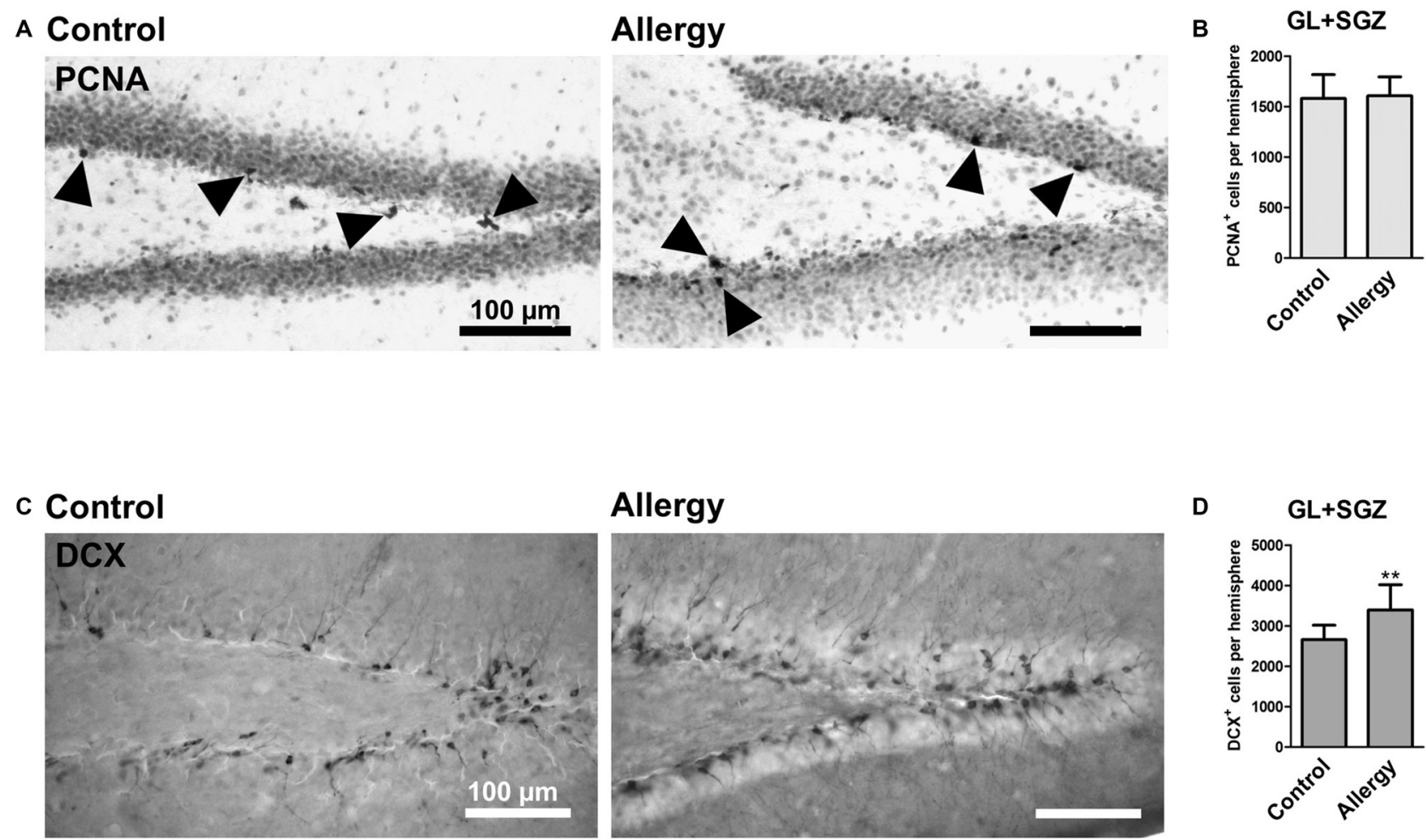

FIGURE 5 | More DCX+ immature neurons, but unchanged cell proliferation, in the hippocampal dentate gyrus. (A) Proliferating cells stained with PCNA (arrowheads) in controls and the allergy group. (B) Allergic mice and controls had the same number of PCNA ${ }^{+}$cells in GL and SGZ of the dentate gyrus. (C) DCX ${ }^{+}$ immature neurons in controls and allergy group. (D) Allergic mice had significantly more DCX+ cells in GL and SGZ. Values are depicted as Mean + SD (control: $n=9$, allergy: $n=10$ ). Statistical significance was evaluated using independent samples $t$-tests and is indicated in comparison to the control group $\left({ }^{*} p<0.05,{ }^{* *} p<0.01,{ }^{* * *} p<0.001\right)$. Scale bars: $100 \mu \mathrm{m}$. 
A

Control

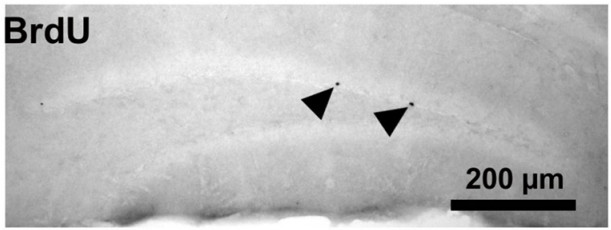

C

\section{Control}
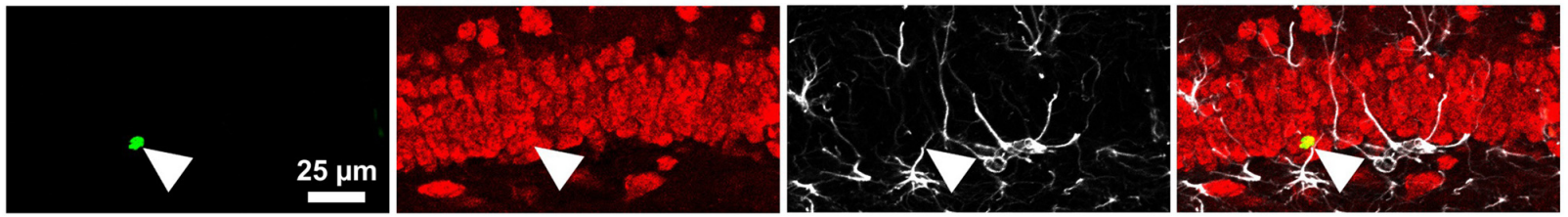

\section{Allergy}
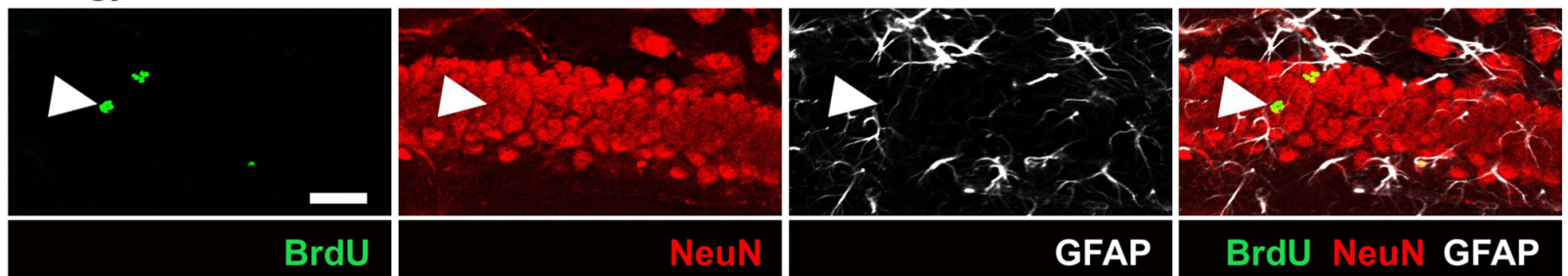

D

GL+SGZ

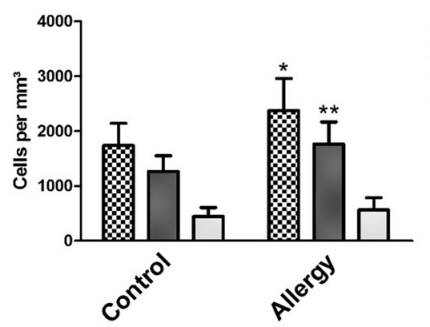

B

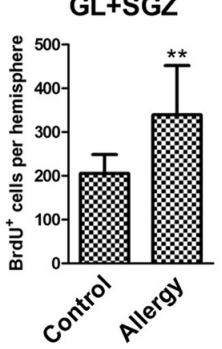

GFAP BrdU NeuN GFAP

FIGURE 6 | More $\mathrm{BrdU}^{+}$and $\mathrm{BrdU}^{+} \mathrm{NeuN}^{+}$cells in the hippocampal dentate gyrus. (A) BrdU ${ }^{+}$cells in the dorsal dentate gyrus. BrdU was injected once 4 weeks before the end of the experiment. (B) Increased number of $\mathrm{BrdU}^{+}$cells in the hippocampal neurogenic niche in allergic mice. (C) Triple labeling of BrdU (green), $\mathrm{NeuN}^{+}$mature neurons (red) and $\mathrm{GFAP}^{+}$astrocytes (white). BrdU ${ }^{+} \mathrm{NeuN}^{+}$mature neurons are indicated by arrowheads. (D) In allergic mice not only the number of $\mathrm{BrdU}^{+}$cells, but also of $\mathrm{BrdU}^{+} \mathrm{NeuN}^{+}$mature neurons increased in comparison to controls. (E) The percentage of BrdU ${ }^{+}$cells which became mature $\mathrm{NeuN}^{+}$neurons or GFAP ${ }^{+}$radial glia (or astrocytes) remained unchanged. Values are depicted as Mean + SD. (control: $n=9$, allergy: $n=10$ ). Statistical significance was evaluated using independent samples $t$-tests and is indicated in comparison to the control group $\left({ }^{*} p<0.05,{ }^{* *} p<0.01\right.$, $\left.{ }^{* * *} p<0.001\right)$. Scale bars: (A) $200 \mu \mathrm{m}$, (C) $25 \mu \mathrm{m}$.

unaffected, suggesting that allergy affects predominantly antigen presentation.

At first glance, our findings are in contrast to numerous studies which found that microglia are activated by systemic inflammation (reviewed in Hoogland et al., 2015). However, those studies exclusively used stimuli inducing $\mathrm{T}_{\mathrm{H}} 1$-polarized immune responses, i.e., LPS, bacteria, or viruses (reviewed in Hoogland et al., 2015), which could explain the different outcome. Moreover, in our allergy model, the deactivation of microglia seemed to be specific for the hippocampal dentate gyrus, since we actually observed an activation of microglia accompanied by upregulation of MHCII and CD68 in the OB (Figure 4). The OB is not only the region into which SVZderived newly generated neurons are integrated, but also seems to contain an especially reactive sub-population of microglia (Lalancette-Hebert et al., 2009), which could explain why 


\section{A \\ Control}

BrdU
Allergy

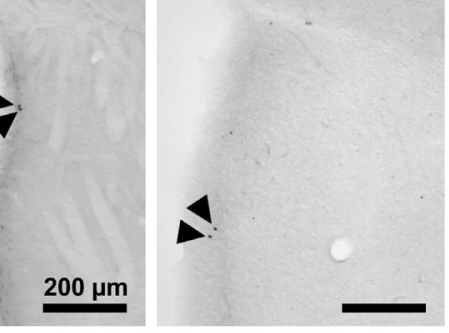

B

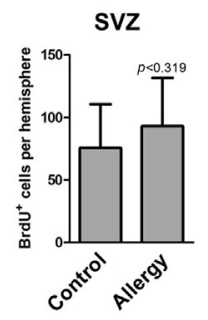

C

\section{Control}
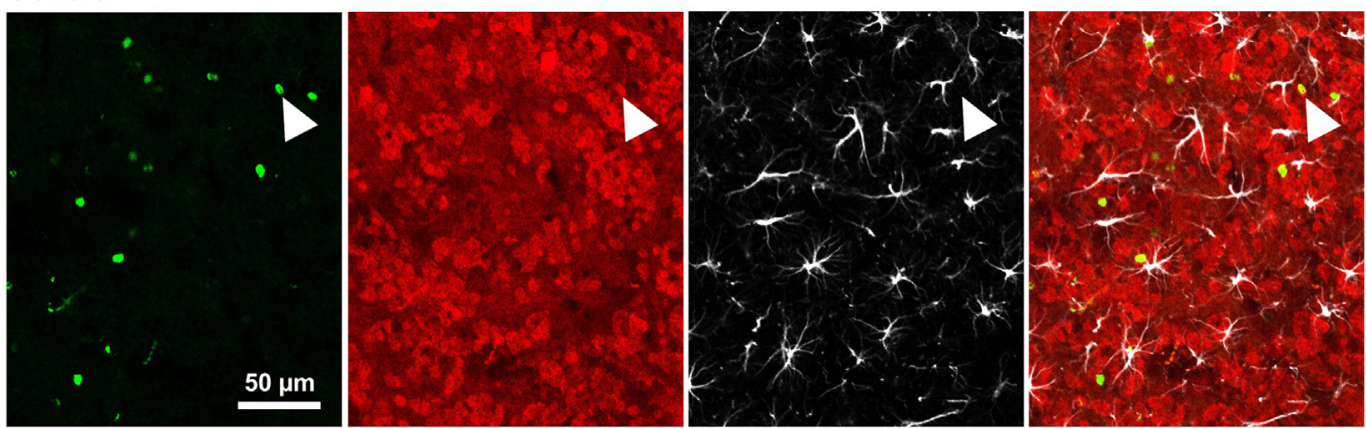

\section{Allergy}
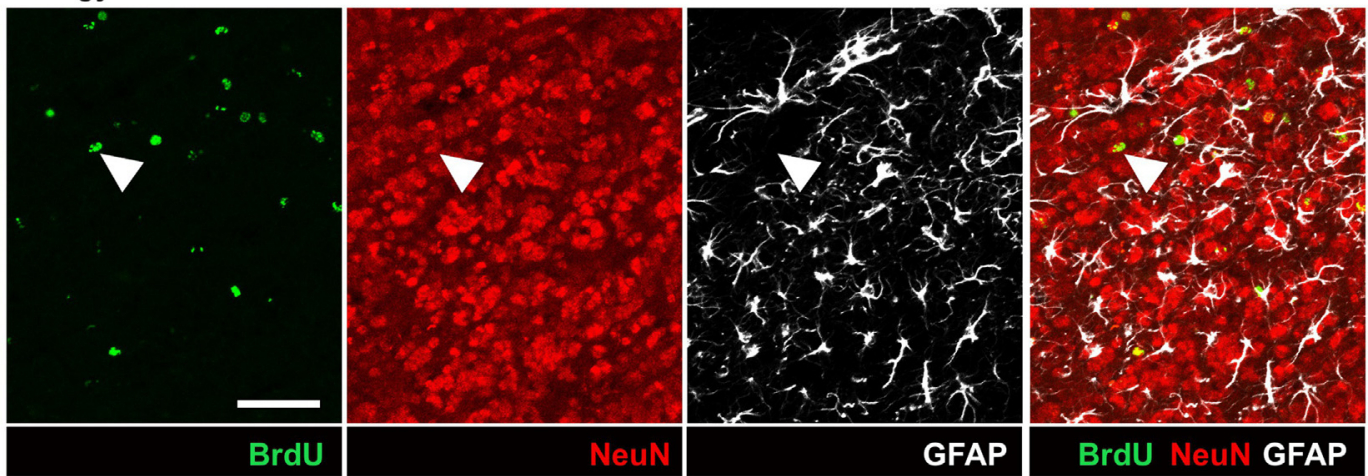

D

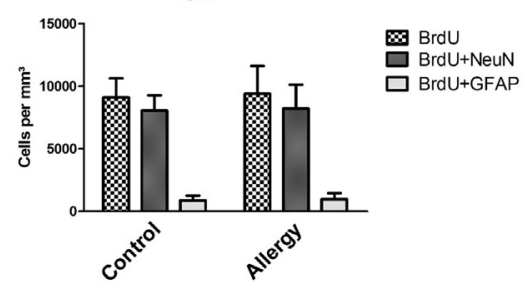

E

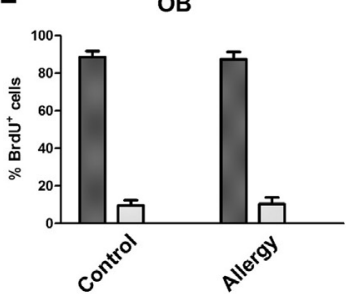

FIGURE 7 | Unchanged number of $\mathrm{BrdU}^{+}$cells in the subventricular zone (SVZ) and no alterations in cell fate of BrdU ${ }^{+}$cells in the OB. (A) BrdU labeling in the SVZ. Arrowheads indicate BrdU ${ }^{+}$cells. (B) There is no significant difference in the number of BrdU ${ }^{+}$cells in the SVZ between controls and allergic mice. (C) BrdU labeling in the OB. The images show a triple labeling of BrdU (green) NeuN (red) and GFAP (white). Arrowheads indicate BrdU ${ }^{+}$NeuN ${ }^{+}$cells. (D,E) Neither the density (D) nor the percentage (E) of BrdU ${ }^{+} \mathrm{NeuN}^{+}$or BrdU ${ }^{+} \mathrm{GFAP}^{+}$cells in the OB differs significantly between controls and allergic mice. Values are depicted as Mean + SD (control: $n=9$, allergy: $n=10$ ). Statistical significance was evaluated using independent samples $t$-tests and is indicated in comparison to the control group $\left({ }^{*} p<0.05,{ }^{* *} p<0.01,{ }^{* * *} p<0.001\right)$. Scale bars: (A) $200 \mu \mathrm{m}$, (C) $50 \mu \mathrm{m}$. 
allergy has an opposite effect on microglia in this region. Alternatively, the intranasal delivery of the allergen might have a much more pronounced effect on the OB system compared to the hippocampus. For this reason, it might be interesting to investigate whether this difference between hippocampal and $\mathrm{OB}$ microglia is also present in allergy models affecting other parts of the organism, e.g., the skin.

Why are microglia deactivated in the hippocampus of allergic mice? It is tempting to assume that this might be a regulatory mechanism protecting the hippocampus, which is central for many important processes, from the immune response in the periphery. An alternative hypothesis would be that this downregulation is directly caused by the elevated levels of $\mathrm{T}_{\mathrm{H}} 2$ cytokines in the blood. It is even more challenging to speculate about the functional consequences of this observed downregulation of microglial activation below the normal "surveying state" in the young hippocampus. If immune surveillance in the hippocampus is down-regulated for extended periods, this may have detrimental consequences. However, with the current experimental set-up we do not know if this microglial deactivation is transient or persists for longer periods. Of course, the allergy-induced changes in hippocampal microglia were rather subtle, which could be due to the fact that the starting point for the down-regulation was a young healthy condition. Therefore, it would be highly interesting to investigate what allergy does to microglia in the aged CNS, which might already be somewhat primed for a pro-inflammatory activation (Norden and Godbout, 2013).

Concomitantly with microglial deactivation, hippocampal neurogenesis was increased, i.e., we observed higher numbers of $\mathrm{DCX}^{+}$immature neurons and $\mathrm{BrdU}^{+} \mathrm{NeuN}^{+}$mature neurons. Since BrdU was injected after the sensitization period (4 weeks before the end of the experiment) and the allergen challenge started only 4 days before the animals were sacrificed, it seems that already the sensitization has an impact on hippocampal neurogenesis. With the current experimental setup it is only possible to analyze the cumulative effect of both phases, but it would be interesting to study the effect of sensitization alone, and further time points in which also the challenge period is extended. Additionally, it would be worth investigating whether alternative sensitization and challenge routes (e.g., in a model for food allergy) have a similar impact on microglia and neurogenesis in the hippocampus.

So far, we can only hypothesize that the observed increase in hippocampal neurogenesis may also have functional consequences on long-term potentiation or learning and memory. For this, further studies including electrophysiological analysis and behavioral tests are needed.

We did not observe any changes in proliferation at the end of the challenge period. This is in contrast to a study which showed that in immature mice, chronic asthma leads to a reduced proliferation in the hippocampal neurogenic niche (Guo et al., 2013). An explanation for these different results could be that the latter study particularly investigated animals of a very young and thus, probably more vulnerable age, starting the OVA sensitization in 3-weeks-old mice and then extended the OVA challenge over a period of 9 weeks (Guo et al., 2013), whereas the present allergy model started in young adult mice (2-months-old) and the actual challenge period only lasted for 4 days. Moreover, commercially available OVA often contains substantial levels of LPS, which lead to additional and potentially confounding immune responses, whereas the Phl p 5 used in the present study was essentially LPS-free. However, similar to the study of Guo et al. (2013), also in our model an increase of serum levels of VEGF $\alpha$ was observed. Within the neurogenic niche, VEGF $\alpha$ supports neurogenesis (Schänzer et al., 2004; reviewed in Kokaia et al., 2012), and it also has been shown that peripheral VEGF is necessary for exercise-induced neurogenesis (Fabel et al., 2003). Taken together, these results suggest that a peripheral increase of VEGF might affect neurogenesis, but this is probably context-dependent.

High serum levels of CCL11 (eotaxin-1) were recently described to inhibit hippocampal neurogenesis (Villeda et al., 2011). While in the BAL fluid, as expected, elevated levels of CCL11 were only found in the allergy group, in serum both, control mice as well as allergic mice, displayed high levels of CCL11. In fact, serum levels of CCL11 were even slightly decreased in allergic mice. This is in line with data showing that eotaxin is elevated in nasal secretion of allergic patients during the pollen season, whereas no difference was observed in eotaxin serum levels-neither in or out of pollen season, nor between healthy and allergic donors (Pullerits et al., 2000).

Depending on the type of immune response, systemic inflammation might elicit diverse effects on the CNS. Our data suggests that a $\mathrm{T}_{\mathrm{H}}$ 2-polarized allergic immune response might promote neurogenesis and down-regulate microglia in the hippocampus. However, at the moment it is not clear if this also has a beneficial effect on CNS functions and what happens if this immune response persists for a longer time. Clearly, more experiments investigating the impact of different types of systemic inflammation on the CNS are needed to further the understanding about the interplay between peripheral immune activation and CNS functions.

\section{AUTHOR CONTRIBUTIONS}

BK: designed the study, analyzed and interpreted data, did histology and microscopy, and drafted the manuscript. HM: participated in the histology. SS participated in the analysis of the immunological parameters in sera and lung fluids. JT: participated in the design of the study and discussion of the results. RW: designed the study, analyzed and interpreted data, carried out the animal treatments and analysis of the blood and lung parameters. LA: participated in the study design and coordination, and the discussion of the results. All authors contributed to revising the manuscript and approved the final version.

\section{FUNDING}

The research leading to these results has received funding from the European Union's Seventh Framework Programme (FP7/2007-2013) under grant agreement number HEALTHF2-2011-278850 (INMiND) and by the Research Fund of 
the Paracelsus Medical University Salzburg (PMU-FFF) as a RISE Project under grant agreement R-13/02/046-KLE, and the Allergy-Cancer-BioNano Research Center of the University of Salzburg.

\section{REFERENCES}

Bieber, T. D. (2011). "Atopic eczema and contact dermatitis," in WAO White Book on Allergy, eds R. Pawankar, G. W. Canonica, S. T., Holgate and R. F. Lockey (Milwaukee, WI: World Allergy Organization).

Blackman, J. A., and Conaway, M. R. (2012). Changes over time in reducing developmental and behavioral comorbidities of asthma in children. J. Dev. Behav. Pediatr. 33, 24-31. doi: 10.1097/DBP.0b013e31823 96895

Blackman, J. A., and Gurka, M. J. (2007). Developmental and behavioral comorbidities of asthma in children. J. Dev. Behav. Pediatr. 28, 92-99. doi: 10. 1097/01.dbp.0000267557.80834.e5

Bloemen, K., Verstraelen, S., Van Den Heuvel, R., Witters, H., Nelissen, I., and Schoeters, G. (2007). The allergic cascade: review of the most important molecules in the asthmatic lung. Immunol. Lett. 113, 6-18. doi: 10.1016/j.imlet. 2007.07.010

Boche, D., Perry, V. H., and Nicoll, J. A. (2013). Review: activation patterns of microglia and their identification in the human brain. Neuropathol. Appl. Neurobiol. 39, 3-18. doi: 10.1111/nan.12011

Bond, A. M., Ming, G. L., and Song, H. (2015). Adult mammalian neural stem cells and neurogenesis: five decades Later. Cell Stem Cell 17, 385-395. doi: 10.1016/j. stem.2015.09.003

Brozek, J. L., Bousquet, J., Baena-Cagnani, C. E., Bonini, S., Canonica, G. W., Casale, T. B., et al. (2010). Allergic Rhinitis and its Impact on Asthma (ARIA) guidelines: 2010 revision. J. Allergy Clin. Immunol. 126, 466-476. doi: 10.1016/j. jaci.2010.06.047

Bozek, A., Krajewska, J., and Jarzab, J. (2010). The improvement of cognitive functions in patients with bronchial asthma after therapy. J. Asthma. 47, 1148-1152. doi: 10.3109/02770903.2010.513077

Cunningham, C. (2013). Microglia and neurodegeneration: the role of systemic inflammation. Glia 61, 71-90. doi: 10.1002/glia.22350

Cunningham, C., Campion, S., Lunnon, K., Murray, C. L., Woods, J. F., Deacon, R. M., et al. (2009). Systemic inflammation induces acute behavioral and cognitive changes and accelerates neurodegenerative disease. Biol. Psychiatry 65, 304-312. doi: 10.1016/j.biopsych.2008. 07.024

Czirr, E., and Wyss-Coray, T. (2012). The immunology of neurodegeneration. J. Clin. Invest. 122, 1156-1163. doi: 10.1172/JCI58656

de Theije, C. G., Wu, J., Koelink, P. J., Korte-Bouws, G. A., Borre, Y., Kas, M. J., et al. (2014). Autistic-like behavioural and neurochemical changes in a mouse model of food allergy. Behav. Brain Res. 261, 265-274. doi: 10.1016/j.bbr.2013. 12.008

Eriksson, U. K., Gatz, M., Dickman, P. W., Fratiglioni, L., and Pedersen, N. L. (2008). Asthma, eczema, rhinitis and the risk for dementia. Dement. Geriatr. Cogn. Disord. 25, 148-156. doi: 10.1159/000112729

Fabel, K., Fabel, K., Tam, B., Kaufer, D., Baiker, A., Simmons, N., et al. (2003). VEGF is necessary for exercise-induced adult hippocampal neurogenesis. Eur. J. Neurosci. 18, 2803-2812. doi: 10.1111/j.1460-9568.2003.03041.x

Fiocchi, A. (2011). "Food allergy," in WAO White Book on Allergy, eds R. Pawankar, G. W. Canonica, S. T. Holgate, and R. F. Lockey, (Milwaukee, WI: World Allergy Organization).

Galli, S. J., Tsai, M., and Piliponsky, A. M. (2008). The development of allergic inflammation. Nature. 454, 445-454. doi: 10.1038/nature07204

Gebara, E., Sultan, S., Kocher-Braissant, J., and Toni, N. (2013). Adult hippocampal neurogenesis inversely correlates with microglia in conditions of voluntary running and aging. Front. Neurosci. 7:145. doi: 10.3389/fnins.2013. 00145

Gemma, C., and Bachstetter, A. D. (2013). The role of microglia in adult hippocampal neurogenesis. Front Cell Neurosci. 7:229. doi: 10.3389/fncel.2013. 00229

\section{ACKNOWLEDGMENTS}

We are very thankful for the excellent technical assistance of Pia Zaunmair.

Guo, R. B., Sun, P. L., Zhao, A. P., Gu, J., Ding, X., Qi, J., et al. (2013). Chronic asthma results in cognitive dysfunction in immature mice. Exp. Neurol. 247, 209-217. doi: 10.1016/j.expneurol.2013.04.008

Hartgerink-Lutgens, I., Vermeeren, A., Vuurman, E., and Kremer, B. (2009). Disturbed cognitive functions after nasal provocation in patients with seasonal allergic rhinitis. Clin. Exp. Allergy 39, 500-508. doi: 10.1111/j.1365-2222.2009. 03200.x

Henry, C. J., Huang, Y., Wynne, A. M., and Godbout, J. P. (2009). Peripheral lipopolysaccharide (LPS) challenge promotes microglial hyperactivity in aged mice that is associated with exaggerated induction of both pro-inflammatory IL-1beta and anti-inflammatory IL-10 cytokines. Brain Behav. Immun. 23, 309-317. doi: 10.1016/j.bbi.2008.09.002

Holgate, S. T., Bodey, K. S., Janezic, A., Frew, A. J., Kaplan, A. P., and Teran, L. M. (1997). Release of RANTES, MIP-1 alpha and MCP-1 into asthmatic airways following endobronchial allergen challenge. Am. J. Respir. Crit. Care Med. 156, 1377-1383. doi: 10.1164/ajrccm.156.5.9610064

Holgate, S. T., and Polosa, R. (2008). Treatment strategies for allergy and asthma. Nat. Rev. Immunol. 8, 218-230. doi: 10.1038/nri2262

Hoogland, I. C., Houbolt, C., van Westerloo, D. J., van Gool, W. A., and van de Beek, D. (2015). Systemic inflammation and microglial activation: systematic review of animal experiments. J. Neuroinflammation 12:114. doi: 10. 1186/s12974-015-0332-6

Jurgens, H. A., Amancherla, K., and Johnson, R. W. (2012). Influenza infection induces neuroinflammation, alters hippocampal neuron morphology and impairs cognition in adult mice. J. Neurosci. 32, 3958-3968. doi: 10. 1523/JNEUROSCI.6389-11.2012

Jurgens, H. A., and Johnson, R. W. (2012). Environmental enrichment attenuates hippocampal neuroinflammation and improves cognitive function during influenza infection. Brain Behav. Immun. 26, 1006-1016. doi: 10.1016/j.bbi. 2012.05.015

Kahn, M. S., Kranjac, D., Alonzo, C. A., Haase, J. H., Cedillos, R. O., McLinden, K. A., et al. (2012). Prolonged elevation in hippocampal A $\beta$ and cognitive deficits following repeated endotoxin exposure in the mouse. Behav. Brain Res. 229, 176-184. doi: 10.1016/j.bbr.2012.01.010

Kandasamy, M., Lehner, B., Kraus, S., Sander, P. R., Marschallinger, J., Rivera, F. J., et al. (2014). TGF-beta signalling in the adult neurogenic niche promotes stem cell quiescence as well as generation of new neurons. J. Cell. Mol. Med. 18, 1444-1459. doi: 10.1111/jcmm. 12298

Kettenmann, H., Hanisch, U. K., Noda, M., and Verkhratsky, A. (2011). Physiology of microglia Physiol. Rev. 91, 461-553. doi: 10.1152/physrev.000 11.2010

Kokaia, Z., Martino, G., Schwartz, M., and Lindvall, O. (2012). Cross-talk between neural stem cells and immune cells: the key to better brain repair? Nat. Neurosci. 15, 1078-1087. doi: 10.1038/nn.3163

Kranjac, D., McLinden, K. A., Deodati, L. E., Papini, M. R., Chumley, M. J., and Boehm, G. W. (2012). Peripheral bacterial endotoxin administration triggers both memory consolidation and reconsolidation deficits in mice. Brain Behav. Immun. 26, 109-121. doi: 10.1016/j.bbi.2011.08.005

Kuna, P., Lazarovich, M., and Kaplan, A. P. (1996). Chemokines in seasonal allergic rhinitis. J. Allergy Clin. Immunol. 97, 104-112. doi: 10.1016/s00916749(96)70288-9

Lalancette-Hebert, M., Phaneuf, D., Soucy, G., Weng, Y. C., and Kriz, J. (2009). Live imaging of Toll-like receptor 2 response in cerebral ischaemia reveals a role of olfactory bulb microglia as modulators of inflammation. Brain 132, 940-954. doi: 10.1093/brain/awn345

Marín-Burgin, A., and Schinder, A. F. (2012). Requirement of adult-born neurons for hippocampus-dependent learning. Behav. Brain Res. 227, 391-399. doi: 10. 1016/j.bbr.2011.07.001

Matthiesen, F., and Løwenstein, H. (1991). Group V allergens in grass pollens. I. Purification and characterization of the group V allergen from Phleum pratense 
pollen, Phl p V. Clin. Exp. Allergy 21, 297-307. doi: 10.1111/j.1365-2222.1991. tb01661.x

Norden, D. M., and Godbout, J. P. (2013). Review: microglia of the aged brain: primed to be activated and resistant to regulation. Neuropathol. Appl. Neurobiol. 39, 19-34. doi: 10.1111/j.1365-2990.2012.01306.x

Pawankar, R. (2011). "Rhinitis, conjunctivitis and rhinosinusitis," in WAO White Book on Allergy, eds R. Pawankar, G. W. Canonica, S. T. Holgate and R. F. Lockey (Milwaukee, WI: World Allergy Organization).

Perry, V. H. (2010). Contribution of systemic inflammation to chronic neurodegeneration. Acta Neuropathol. 120, 277-286. doi: 10.1007/s00401-0100722-x

Pullerits, T., Lindén, A., Praks, L., Cardell, L. O., and Lötvall, J. (2000). Upregulation of nasal mucosal eotaxin in patients with allergic rhinitis during grass pollen season: effect of a local glucocorticoid. Clin. Exp. Allergy 30, 1469-1475. doi: 10.1046/j.1365-2222.2000.00993.x

Sansone, R. A., and Sansone, L. A. (2011). Allergic rhinitis: relationships with anxiety and mood syndromes. Innov. Clin. Neurosci. 8, 12-17.

Sarlus, H., Eyjolfsdottir, H., Eriksdotter, M., Oprica, M., and Schultzberg, M. (2015). Influence of allergy on immunoglobulins and amyloid- $\beta$ in the cerebrospinal fluid of patients with Alzheimer's disease. J. Alzheimers Dis. 48, 495-505. doi: 10.3233/JAD-143147

Sarlus, H., Höglund, C. O., Karshikoff, B., Wang, X., Lekander, M., Schultzberg, M., et al. (2012). Allergy influences the inflammatory status of the brain and enhances tau-phosphorylation. J. Cell. Mol. Med. 16, 2401-2412. doi: 10.1111/j.1582-4934.2012.01556.x

Sarlus, H., Wang, X., Cedazo-Minguez, A., Schultzberg, M., and Oprica, M. (2013). Chronic airway-induced allergy in mice modifies gene expression in the brain toward insulin resistance and inflammatory responses. J. Neuroinflammation 10:99. doi: 10.1186/1742-2094-10-99

Schänzer, A., Wachs, F. P., Wilhelm, D., Acker, T., Cooper-Kuhn, C., Beck, H., et al. (2004). Direct stimulation of adult neural stem cells in vitro and neurogenesis in vivo by vascular endothelial growth factor. Brain Pathol. 14, 237-248. doi: 10.1111/j.1750-3639.2004.tb00060.x

Sekerkova, A., Polackova, M., and Striz, I. (2012). Detection of Phl p 1, Phl p 5, Phl $\mathrm{p} 7$ and $\mathrm{Phl}$ p 12 specific IgE antibodies in the sera of children and adult patients allergic to Phleum pollen. Allergol. Int. 61, 339-346. doi: 10.2332/allergolint.11OA-0372

Sierra, A., Beccari, S., Diaz-Aparicio, I., Encinas, J. M., Comeau, S., and Tremblay, M. E. (2014). Surveillance, phagocytosis and inflammation: how never-resting microglia influence adult hippocampal neurogenesis. Neural Plast. 2014:610343. doi: 10.1155/2014/610343
Sierra, A., Encinas, J. M., Deudero, J. J., Chancey, J. H., Enikolopov, G., OverstreetWadiche, L. S., et al. (2010). Microglia shape adult hippocampal neurogenesis through apoptosis-coupled phagocytosis. Cell Stem Cell 7, 483-495. doi: 10. 1016/j.stem.2010.08.014

Silverberg, J. I., Joks, R., and Durkin, H. G. (2014). Allergic disease is associated with epilepsy in childhood: a US population-based study. Allergy 69, 95-103. doi: 10.1111/all.12319

Tonelli, L. H., Katz, M., Kovacsics, C. E., Gould, T. D., Joppy, B., Hoshino, A., et al. (2009). Allergic rhinitis induces anxiety-like behavior and altered social interaction in rodents. Brain Behav. Immun. 23, 784-793. doi: 10.1016/j.bbi. 2009.02.017

Trikojat, K., Buske-Kirschbaum, A., Schmitt, J., and Plessow, F. (2015). Altered performance in attention tasks in patients with seasonal allergic rhinitis: seasonal dependency and association with disease characteristics. Psychol. Med. 45, 1289-1299. doi: 10.1017/S00332917140 02384

Valero, J., Mastrella, G., Neiva, I., Sánchez, S., and Malva, J. O. (2014). Long-term effects of an acute and systemic administration of LPS on adult neurogenesis and spatial memory. Front. Neurosci. 8:83. doi: 10.3389/fnins.2014.00083

Villeda, S. A., Luo, J., Mosher, K. I., Zou, B., Britschgi, M., Bieri, G., et al. (2011). The ageing systemic milieu negatively regulates neurogenesis and cognitive function. Nature 477, 90-94. doi: 10.1038/nature10357

Weinberger, E. E., Isakovic, A., Scheiblhofer, S., Ramsauer, C., Reiter, K., HauserKronberger, C., et al. (2013). The influence of antigen targeting to sub-cellular compartments on the anti-allergic potential of a DNA vaccine. Vaccine 31, 6113-6121. doi: 10.1016/j.vaccine.2013.08.005

Yirmiya, R., and Goshen, I. (2011). Immune modulation of learning, memory, neural plasticity and neurogenesis. Brain Behav. Immun. 25, 181-213. doi: 10 1016/j.bbi.2010.10.015

Conflict of Interest Statement: The authors declare that the research was conducted in the absence of any commercial or financial relationships that could be construed as a potential conflict of interest.

Copyright (c) 2016 Klein, Mrowetz, Thalhamer, Scheiblhofer, Weiss and Aigner. This is an open-access article distributed under the terms of the Creative Commons Attribution License (CC BY). The use, distribution and reproduction in other forums is permitted, provided the original author(s) or licensor are credited and that the original publication in this journal is cited, in accordance with accepted academic practice. No use, distribution or reproduction is permitted which does not comply with these terms. 